\title{
The performance of Islamic vs. conventional banks: Evidence on the suitability of the Basel capital ratios
}

\author{
Mohammad Bitar ${ }^{\mathrm{a}^{*}}$, M. Kabir Hassan ${ }^{\mathrm{b}}$, Kuntara Pukthuanthong ${ }^{\mathrm{c}}$, Thomas Walker ${ }^{\mathrm{a}}$
}

\footnotetext{
a Department of Finance, Concordia University, 1455 Blvd. de Maisonneuve West, Montréal, Canada.

${ }^{b}$ Department of Finance, University of New Orleans, College of Business Administration, New Orleans, LA 70148, United States.

${ }^{\mathrm{c}}$ Department of Finance, University of Missouri, 419 Cornell Hall, Trulaske College of Business, Columbia, MO 65211 United States.

a* Corresponding author. Tel: +1-514-848-2424 ext. 2387, Fax: +1-514-848-4500

E-mail addresses: mohammad.bitar@concordia.ca (M. Bitar), mhassan@uno.edu (M. Hassan), pukthuanthongk@missouri.edu (K. Pukthuanthong), thomas.walker@ concordia.ca (T. Walker).
}

\begin{abstract}
.
This paper examines the effect of various types of bank capital on the profitability and efficiency of conventional and Islamic banks. Our results show that higher quality forms of capital improve the profitability and efficiency for both systems although the results are stronger for conventional banks. The capital effect is more pronounced for large, too-big-to-fail, and highly capitalized banks. The results are robust across various subsamples, alternative profitability and efficiency measures, and different estimation techniques.
\end{abstract}

Key words: Bank capital, Basel capital, profitability, efficiency.

JEL Classification: G21, G28, P43, P47.

We thank participants at the 2016 KFUPM Islamic Banking and Finance Research Conference (Riyadh, Saudi Arabia), the editor, and two anonymous reviewers for constructive comments on an earlier version of our paper. All remaining errors are, of course, our own. 


\section{Introduction}

The severity of the 2007-2009 subprime crisis followed by the European sovereign debt crisis in 2010 and more recently Greece announcing its incapacity to pay its debt to the International Monetary Fund (IMF) (June 2015) has sparked continuous overhauls in financial regulation throughout the financial system. It also encouraged the emergence and the development of alternative and/or complementary financial systems such as Islamic banking and finance ${ }^{1}$. Becoming systemically important in several countries (Song and Oosthuizem, 2014), Islamic banks are expected to reach $\$ 1.6$ trillion in assets with an annual growth rate of $19.7 \%$ during the period 2013 to 2018 (Ernst and Young, 2014). Demirgüç-Kunt et al. (2013) and Imam and Kpodar (2015) ascertain that Islamic banks can also play a key role in promoting financial inclusion ${ }^{2}$ and economic growth in Muslim countries.

Islamic banking can be defined as "a type of finance that respects the principles of Sharia'a" (Gheeraert, 2014, pg. 4). The Arabic term Sharia'a means Islamic law and involves a series of instructions that govern not only the religious life of every Muslim but also all financial and economic aspects. These instructions include five principles that apply to Islamic banks (LópezMejía et al., 2014; Jawadi et al., 2016a, b). First, the risk sharing between Islamic banks and their depositors - in particular investment account holders - provides more protection to the banks; second, Islamic banks are more conservative in their investments because they need to provide stable and competitive returns to their depositors; third, Islamic bank activities are asset-backed and thus directly associated with the real economy; fourth, investment account holders exercise more control on management since they share their risk with the bank; and finally, Islamic banks tend to hold important reserves with central banks because they lack short-term investment activities.

These features of the Islamic banking system raise several regulatory concerns about the development of this industry. Masciandaro (2011), Song and Oosthuizem (2014), and López-Mejía et al. (2014) show that, although several countries are improving their legal, regulatory, and

\footnotetext{
${ }^{1}$ The World Bank Islamic Banking Database reports 394 financial institutions distributed in 57 countries across the globe.

2 The 2014 Global Financial Development Report (GDFR) defines financial inclusion as the percentage of individuals and firms that have access to financial services. According to this concept, having rapid access to financial services is an important indicator that can be used to trace poverty; and it therefore works to ameliorate inequalities and improve prosperity and sustainable economic development between countries.
} 
supervisory framework regarding Islamic banking activities, several challenges persist and require further investigation ${ }^{3}$.

In this paper, we shed light on the effect of banking regulations - in particular the capital ratios implemented by the Basel Committee on Banking and Supervision (BCBS) - on the performance of both Islamic and conventional banks. ${ }^{4}$ More precisely, we analyze the impact of capital on the profitability and efficiency of Islamic and conventional banks. We follow Bitar et al. (2016) and Bitar et al. (2018) and examine the differences and similarities among various forms of capital using an unbalanced sample of 729 banks located in 33 countries over the period 1999-2013. We choose to evaluate the impact of capital ratios because of the tremendous change and rapid development in definitions and approaches used to compute capital ratios. This development not only reflects the importance of complying with regulatory guidelines to avoid financial distress but also the growing regulatory complexities faced by modern banking institutions.

Our results provide important new insights. First, higher capital ratios have a positive and significant impact on the profitability and efficiency of Islamic and conventional banks, suggesting that well capitalized banks have a lower cost of funding, better monitoring and credit risk management, and make wiser lending decisions, which in turn lead to higher profitability and better efficiency. This is in line with the public interest and the moral hazard hypotheses about the importance of capital in improving bank performance and economic growth. Second, the impact of different forms of capital is stronger for conventional than for Islamic banks. Third, we document that our results are primarily driven by larger and too-big-to-fail banks. Fourth, highly capitalized banks, defined as banks whose capital ratios as disclosed by the banks in their annual report far exceed the minimum level required by the banking regulatory authorities, i.e. BCBS, exhibit significantly better performance. We conduct a series of robustness tests that show similar results when we break down our sample into banks in the Middle East and North Africa (MENA) region, the Gulf Cooperation Council (GCC) countries and South East Asia (SEA), and before, during and

\footnotetext{
${ }^{3}$ At the 4th Islamic Banking and Finance Conference held in 2014, Thorsten Beck questioned how regulators should treat Sharia'a compliant finance and proposed two alternative solutions. First, regulators should try to fit Islamic banks into the existing regulatory framework subject to certain exceptions (e.g. Profit Loss Sharing (PLS) transactions). Second, they should create independent regulatory guidelines that deal specifically with Sharia'a compliant finance.

${ }^{4}$ The extant literature finds that cooperation is optimized with a small number of participants. Pattison (2006) shows that Basel I has over 100 adherents and explains why this is not an anomaly.
} 
after the financial crisis. Finally, alternative performance and capital measures, additional macroeconomic and institutional indexes, a truncated regression, a first difference estimation, and a quantile regression approach confirm our earlier findings.

Our research contributes to the existing literature in several ways. First, for the first time, we examine the impact of the Basel guidelines - in term of risk- and non-risk-based regulatory capital ratios - on the profitability and efficiency of commercial and Islamic banks. Second, our study is different because we use eight capital ratios including risk-based and non-risk-based capital measures in addition to traditional capital ratios to compare and examine whether the Basel Accords have a pronounced effect on the performance of commercial versus Islamic banks. We use risk and non-risk based capital ratios because of the renewed debate on the effectiveness of capital ratios. For instance, Demirgüç-Kunt et al. (2013) and Anginer and Demirgüç-Kunt (2014) ask what kind of capital banks need to maintain and how to structure the capital. This corroborates with Haldane (2012), Dermine (2015) and Cathcart et al. (2015) who shed doubt on the ability of risk weighted assets in reflecting actual bank risk exposure, especially during the subprime crisis. This paper adds to the literature on the effectiveness of capital (i.e. the Basel risk-based capital ratios versus traditional non-risk based capital ratios) by examining Islamic banks. Finally, we utilize several regression techniques and combine parametric approaches (e.g. OLS regressions and truncated regressions) and non-parametric approaches (quantile regressions) to examine the robustness of our results.

The rest of the paper is organized as follows. Section 2 reviews the literature. Section 3 describes the data set, provides definitions and sources for all variables, and discusses our methodology. Section 4 examines the impact of regulatory capital on bank profitability and efficiency. Section 5 concludes.

\section{Literature review}

\subsection{Capital ratios and the performance of conventional banks}

The nature of the relationship between regulations and bank performance is not yet conclusive and often suggests mixed results. Several hypotheses have been put forward to explain this association. Ayadi et al. (2015) propose the "public interest" and "private interest" hypotheses to 
explain the impact of regulations on bank performance. The public interest view suggests that governments and regulatory authorities have necessary information to better regulate the financial system especially with market failures. This increasing role in the economy promotes public interest and can lead to a better functioning of banks by nourishing competition and ameliorating effective governance and thus bank performance. Choretareas et al. (2012) explain that governments with powerful supervision can eventually improve bank efficiency by reducing corruption in bank lending activities. Their results are in line with those of Bitar et al. (2016) and Bitar et al. (2018) who examine the effect of capital on bank efficiency and profitability in the Middle East and North Africa (MENA) and the Organization for Economic Co-operation and Development (OECD) regions, respectively. In contrast, defenders of the private interest hypothesis argue that well-conceived regulation can distort bank efficiency by putting constraints on firms and channel resources to few special-interest groups at the expense of the broader public.

Another hypothesis, which coincides with the public interest view, is the "moral hazard" hypothesis. This hypothesis suggests that banks are required to hold more capital to impede moral hazard and thus agency conflicts between bank managers and shareholders (Fiordelisi et al., 2011; Barth et al., 2013). ${ }^{5}$ For instance, bank managers have an incentive to take excessive risk at the expense of bank shareholders and by exploiting flat-deposit insurance schemes. Accordingly, higher capital ratios play a key role in alleviating moral hazard, reducing cost and aligning the interests of bank managers and depositors, which results in better screening and more efficient lending activities. ${ }^{6}$ Barth et al. (2013) investigate the relationship between banking regulations and efficiency. Their results suggest that banking regulation, supervision, and monitoring are important determinants of bank efficiency. For instance, capital stringency and equity to asset ratios are positively associated with bank efficiency.

\footnotetext{
${ }^{5}$ Moral hazard is generated from the agency conflicts between bank managers and shareholders where managers benefit from information asymmetry and take on excessive risk at the expense of shareholders.

${ }^{6}$ While this paper solely focuses on the impact of capital on bank performance, the literature provides abundant research on the association between capital, regulation and bank risk. For instance, Klomp and De Haan (2012) employ factors extracted using factor analysis and quantile regressions to show that capital regulations and supervisory control reduce moral hazard and thus bank asset risk, especially for high-risk banks. Similar results are also provided by Klomp and De Haan (2014) and Shehzad and De Haan (2015). We have tested the moral hazard hypothesis using three proxies of bank risk - the standard deviation of return on equity, the risk-adjusted return on assets, and the ratio of loan loss reserves to gross loans - to examine the impact of capital on bank risk. The results show that banks with higher capital ratios have lower earnings volatility, higher adjusted returns, and commensurate for risk by holding higher reserves for loan losses. We are grateful to an anonymous referee for raising this point. We do not show the results for expositional brevity, but they are available from the authors upon request.
} 
Examining an unbalanced panel of 5,227 bank observations in 22 European Union countries, Chortareasa et al. (2012) find that capital have a positive effect on bank efficiency and a negative effect on costs. Their results suggest that higher capitalization alleviates the agency problems between managers and shareholders. Hence, the latter will have greater incentives to monitor management performance and ensure that a given bank is efficient. This argument is supported by studies that examine the effect of capital on bank efficiency and profitability. For instance, Lee and Hsieh (2013) find a positive association between the capital and profitability of commercial, cooperative, investment, and other banks in 42 Asian countries. Bitar et al. (2016) use a panel of 178 banks from 17 MENA countries and compare the effect of risk- versus non-risk-based capital ratios on bank performance. Consistent with the moral hazard hypothesis, ${ }^{7}$ their findings indicate that capital in the form of common equity and Tier1 capital is more effective in improving bank performance compared to capital-like instruments or Tier2 capital. Bitar et al. (2018) obtain similar results when using a sample of 1,992 banks from OECD countries. Finally, Demirgüç-Kunt et al. (2013) find a positive impact of capital on bank stock returns for a sample of developed countries, especially in the crisis period and for larger banks.

While the literature provides important empirical support for the public interest and the moral hazard hypotheses, which suggest a positive association between capital regulation and bank performance, it also posits a negative impact. For instance, Berger and Di Patti (2006) develop the agency cost hypothesis, which suggests that high leverage or low capital ratios ameliorate bank efficiency. Some early banking studies also claim that capital ratios should be negatively associated with bank performance by arguing that higher capital ratios may alter the demands of investors who may thus accept lower rates of return. This is due to the fact that higher capital ratios alleviate banks' risk taking and cause investors to accept lower returns on their investments (Park and Weber, 2006). In this context, Altunbas et al. (2007) report a negative relationship between bank efficiency and bank capital and suggest that inefficient European banks hold more capital than efficient ones. Their results are in line with those obtained by Goddard et al. (2013, pg. 15) who argue that "capitalized banks are less risky and therefore tend to generate lower returns".

\footnotetext{
${ }^{7}$ Another possible explanation for the positive relationship between capital and efficiency is provided by Carvallo and Kasman (2005) and Ariff and Can (2008) who argue that efficient banks are more profitable and thus hold higher capital buffers as retained profits.
} 


\subsection{The capital and performance of Islamic banks}

While there is growing body of literature that compares the efficiency of Islamic and conventional banks, the question whether capital ameliorate or impede the efficiency of these institutions is still far from being answered.

Pasiouras et al. (2009) argue that capital can influence the efficiency of the banking system for several reasons. First, by definition banks are financial intermediaries that transform their inputs (e.g. investment deposits in the case of Islamic banks) into outputs (i.e. mark-up transactions and profit loss sharing transactions in the case of Islamic banks). Therefore, capital stringency may influence the quantity and the quality of lending activities. Second, requiring banks to commensurate their capital ratios with the amount of risk taken may affect how managers allocate their bank's asset portfolio and may alter the level of returns they are able to generate. Finally, capital ratios may shift banks' decisions regarding the mix of deposits and equity employed to finance their activities. Rosman et al. (2014) examine the determinants of Islamic bank efficiency for the 2007/2010 period and find a positive association between capital and bank efficiency. The authors explain that Islamic banks hold higher capital buffers to protect against future losses. In addition, because more efficient banks are probably less leveraged (i.e. have more equity), they enjoy a lower cost of capital and thus are more efficient.

On a theoretical level, Islamic banks can benefit from applying PLS principles to IAHs; therefore, they can take on more leverage and generate higher profits to satisfy shareholders at the expense of IAHs who bear any potential losses. Accordingly, bank managers and shareholders may continue to attract more IAHs and take on more leverage, which reduces the agency costs between both parties. This implicit agreement provides higher profits to the shareholders of Islamic banks while ameliorating the reputation, salary, and bonuses of Islamic bank managers. In other words, the investment accounts of Islamic banks may be used as leverage to maximize bank profits at the expense of bank IAHs and the banks' capital position, thereby suggesting that higher leverage and thinner capital ratios ameliorate bank efficiency (Berger and Di Patti, 2006).

However, on a practical level, Islamic banks cannot always channel losses to IAHs because eventually they will no longer invest with Islamic banks. IAHs could withdraw their money causing liquidity and solvency problems. One solution is that Islamic banks maintain profit smoothing 
reserves ${ }^{8}$ which will enable Islamic banks to channel retained earnings from these reserves to remunerate IAH accounts and avoid any possible withdrawals, especially when competing with conventional banks. Yet, Islamic banks need to adjust their equity base in case of severe losses or when their reserves are no longer capable of providing profits to IAHs (Bitar et al., 2017). As a result, they may decide to maintain higher capital ratios than conventional banks to avoid any possible solvency problems. This can also create incentives for bank shareholders to better control bank managers' investment decisions. Higher capital ratios force bank owners to absorb losses using their own resources as a response to a "more skin in the game" policy instead of seeking a bailout through public funds (Demirgüç-Kunt et al., 2013), thus supporting the moral hazard hypothesis cited above.

Based on the results of these empirical studies, we formulate the following hypotheses:

H.1: Increased capital ratios are positively associated with the profitability and efficiency of conventional banks.

H.2: Increased capital ratios are positively associated with the profitability and efficiency of Islamic banks.

Finally, the Basel III agreement could penalize Islamic banks because they lack experience and efficiency in liquidity management, and are restricted by Sharia's principle in their use of debt and collateral instruments. Thus, we address the question whether higher forms of capital have the same or a different impact on Islamic and conventional banks by posing the following hypothesis:

H.3: Increased capital ratios have a more pronounced effect on the profitability and the efficiency of conventional banks compared to Islamic banks.

\section{Sample, Methodology and Variables}

\subsection{Sample}

We use Bankscope as a primary source of data for this study (Abedifar et al., 2013; DemirgüçKunt et al., 2013; Anginer and Demirgüç-Kunt, 2014). For each bank in the sample, we retrieve annual data from 1999 to 2013. Our data is unbalanced and the number of conventional (Islamic)

\footnotetext{
${ }^{8}$ See section 2.1 and note 9.
} 
banks varies between 377 (44) banks (at the lowest) in 1999 and 590 (139) banks in 2012 (at the highest). Macroeconomic data such as the GDP growth rate is obtained through the World Bank's World Development Indicators. A bank is excluded from the sample if it does not have at least 3 continuous observations. In addition, we remove countries that have data for fewer than 4 banks.

\subsection{Regression model}

We examine the relation between capital ratios and bank profitability/efficiency by employing the following basic OLS regression models: ${ }^{9}$

$\mathrm{f}(\text { PROF1\&2, EFF1\&2) })_{\mathrm{ijt}}=\alpha+\varphi \times$ bank_control $_{\mathrm{ijt}}+\beta_{1} \times \mathrm{IBDV} \times$ Capital_ra $_{\mathrm{ijt}}$

$$
+\beta_{2} \times \text { CBDV } \times \text { Capital_ra } \mathrm{ijt}_{\mathrm{i}}+\mathrm{C}_{\mathrm{c}}+\mathrm{Y}_{\mathrm{Y}}+\varepsilon_{\mathrm{i}}
$$

where i refers to bank i's profitability ratios (PROF1 and PROF2) and efficiency scores (EFF1 and EFF2) in country j in year t. Capital_ra are the eight capital ratios, i.e. Tier 1 capital, Tier 2 capital, total capital, common equity, and tangible equity, as expressed in Section 3.3. ${ }^{10}$ Bank_control are bank-level control variables including bank size, the growth of total assets, bank loan engagement, fixed assets and non-operating income. IBDV is a dummy variable that takes on a value of 1 for Islamic banks and 0 for conventional banks while CBDV is a dummy variable that takes on a value of 1 for conventional banks and 0 for Islamic banks. $C_{C}$ and $Y_{y}$ represent country and year fixed effect dummy variables. $\mathrm{C}_{\mathrm{C}}$ and $\mathrm{Y}_{\mathrm{y}}$ are included to mitigate any effect of omitted variables related to each country and year specifications as explained by Demirgüç-Kunt and Anginer (2014). ${ }^{11}$

\footnotetext{
${ }^{9}$ Our regression methodology differs from Beck et al. (2013) and Abedifar et al. (2013) in two aspects: First, we examine the direct impact of capital ratios on both commercial (CBDV) and Islamic banks (IBDV). Second, we measure whether the results are similar or different for both systems.

${ }^{10}$ Except for the capital ratios, all correlation coefficients are below 0.4 . Therefore, we run each model using only one measure of capital to avoid multicollinearity. The Pearson correlation matrix is available from the authors upon request.

${ }^{11}$ We follow Bitar et al. (2017) and cluster at the bank level instead of the country level for two reasons. First, some countries have a much larger number of observations than other countries in the sample. Second, we have thirty three countries. Therefore, clustering at the country level might create biased results.
} 


\subsection{Variable descriptions}

\subsubsection{Measures of profitability and efficiency}

The main objective of this paper is to examine the impact of various definitions of capital on bank profitability and efficiency. We measure profitability using the ratio of net income to three year average assets (PROF1) and the ratio of operating profit to three year average assets (PROF2). These accounting ratios are used to control for any cross-bank differences in terms of performance (Mollah and Zaman, 2015). An increased value indicates a higher level of profitability and operational efficiency. We choose profitability ratios because they are both easy to find and to interpret, especially for comparison studies. However, profitability ratios cannot capture the complete picture of a bank's performance (Bitar et al., 2016; 2018). In addition, there is no reason for preferring one specific ratio as a main measure of bank performance. While previous research typically compares the performance of Islamic and conventional banks using one approach, in this study, we combine financial ratios and efficiency scores.

With regard to efficiency, the literature has mixed views regarding the use of technical efficiency (Barth et al., 2013; Johnes et al., 2014; Ayadi et al., 2016) versus cost and profit efficiency (Ariff and Can, 2008; Pasiouras et al., 2009; ) when examining the determinants of bank efficiency in response to capital, liquidity, profitability, and other regulatory and institutional determinants. Although we do not have any preference for a specific efficiency type, we employ technical efficiency instead of profit efficiency for two reasons. First, a measure based on input-cost and output-revenue would be more appropriate for studies that focus on conventional banks where the underlying objective is profit maximization in contrast to Islamic banks whose main objective is unlikely to be cost minimization or profit maximization (Johnes et al., 2014). Second, the literature is scarce when examining the determinants of bank performance using technical efficiency (Barth et al., 2013; Johnes et al., 2014). Therefore, our study adds to the Islamic banking literature by using technical efficiency along with various profitability measures. We estimate a model ${ }^{12}$ that incorporates four inputs and three outputs. The inputs are: deposits and short term funding (Chortareasa et al. 2012; Barth et al., 2013; Johnes et al., 2014), fixed assets (Rosman et al., 2014; Bitar et al., 2017), overhead as a proxy for general and administrative expenses and loan loss

\footnotetext{
${ }^{12}$ Detailed description of the methodology is available upon request.
} 
provisions as a proxy of risk (Barth et al., 2013). The efficiency literature is divided about the incorporation of loan loss provisions ${ }^{13}$ versus equity to control for a bank's risk exposure. On one hand, researchers such as Johnes et al. (2014) propose to use equity as an indicator of risk taking because data is less available for loan loss provision. On the other hand, Barth et al. (2013) point out that risk can be incorporated by including loan loss provisions in efficiency analyses. The outputs are: total loans (Chortareasa et al. 2012; Barth et al., 2013), other earning assets (Bitar et al., 2017), and other operating income. Barth et al. (2013) argue that an important reason behind the inclusion of other operating income is to avoid any penalization of banks that largely rely on non-traditional activities in their investment portfolio.

\subsubsection{Measures of capital and control variables}

We follow Bitar et al. (2016) and Bitar et al. (2018) and use several definitions of capital ratios. These measures are computed according to the Basel rule using risk-weighted assets (rwa) in the first step. Then, in a second step, we compute the same ratios but use total assets (ta) instead. The objective of such a comparison is to avoid any untruthful assessment related to the calculation of risk-weighted assets (Arnold et al., 2012; Cathcart et al., 2015; Dermine, 2015). The first vector employs three $\operatorname{ratios}^{14}$ : Tier 1 (tier 1/rwa), Tier 2 (tier 2/rwa) and Tier 1 plus Tier 2 divided by riskweighted assets and off-balance sheet exposures (total capital/rwa). Tier 1 capital is the sum of shareholders' funds and perpetual, non-cumulative preference shares. Tier 2 capital is the sum of hybrid capital, subordinated debt, loan loss reserves and valuation reserves. Song and Oosthuizen (2014) and López-Majía et al. (2014) ascertain that Islamic banks have a very small Tier 2 capital ratio because they prohibit instruments such as subordinated debt (e.g. junior security and subordinated loans) that require interest payments. Thus, Basel III should not impact Islamic banks' capital compared to conventional banks. Total capital, known as the capital adequacy ratio, contains Tier 1 and Tier 2 capital, all scaled by risk weighted assets, and must be at least $8 \%$ under the Basel II rules. The second vector incorporates five ratios: Tier 1 to total assets (tier $1 /$ ta), Tier 2 to total assets (tier2/ta), Tier 1 plus Tier 2 divided by total assets (total capital/ta), common equity to assets

\footnotetext{
${ }^{13}$ We compute a basic gross efficiency score model in which we do not control for the risk in bank inputs in the first step (EFF1) and re-calculate our scores by introducing loan loss provisions to control for banking risk (EFF2).

14 The Bankscope database lacks observations regarding Tier 1 capital (tier 1/rwa) and the total capital ratio (total capital/rwa). Therefore, whenever possible, we download the annual reports from the website of each Islamic bank to fill in any missing data.
} 
(common equity/ta), and tangible equity to assets (tangible equity/ta). Bank common equity includes common shares and premium, retained earnings, reserves for general banking risks, and statutory reserves. Tangible common equity removes goodwill and any other intangible assets from its equity.

We also employ a series of bank-level control variables to capture the differences in bank characteristics. We first include the natural logarithm of total assets to control for bank size (size). Second, we use the growth of total assets (growth assets) to control for the development in total bank assets in the current year compared with the previous year. For instance, Abedifar et al. (2013) use this ratio as a proxy for bank growth and development strategies. Third, we use the ratio of net loans to total assets (net loans/ta) because the literature shows that banks that possess a strong loan portfolio are less exposed to risk than other banks that prefer to invest in derivatives, other types of securities, and other non-traditional activities. Fourth, we employ the ratio of fixed assets to assets (fixed assets/ta) to control for the bank's financing activities. According to Beck et al. (2013) this ratio accounts for the opportunity cost that arises from incorporating non-earning assets in the banks' balance sheet. Finally, we control for activities that are not related to bank core operations using non-operating income scaled by total assets. All variables are winsorized at the $1 \%$ and $99 \%$ level to mitigate the effect of outliers.

\section{Empirical results}

\subsection{Descriptive statistics}

Tables 1.A and 1.B present descriptive statistics for all variables. We find that Islamic banks are more profitable and more efficient than conventional banks. For example, the PROF1 average is $1.21 \%$ for Islamic banks and $1.12 \%$ for conventional banks. Similarly, the EFF1 average is $52.36 \%$ for the former and $49.06 \%$ for the latter. We obtain the same results for PROF2, EFF2, and alternative performance measures. T-tests show that Islamic banks are significantly more efficient than conventional banks in terms of PROF2, EFF1, and EFF2. In addition, we find that Islamic banks are more capitalized than conventional counterparts. Risk- and non-risk-based capital ratios (i.e. Tier 1/rwa, Tier 2/rwa, Total capital/rwa as risk-based ratios and Tier 1/ta, Tier 2/ta and Total capital/ta as non-risk-based ratios) in addition to traditional capital ratios (i.e. common equity/ta and tangible equity/ta) confirm our results. However, we show that capital-like or Tier 2 ratios are higher for conventional banks than for Islamic ones, supporting Song and Oosthuizen (2014) and López- 
Majía et al. (2014) who observe a rare use of Tier 2 by Islamic banks. We also note that the number of observations varies significantly between risk-based measures and non-risk based measures. For instance, the ratio of Tier1 capital to risk weighted assets (Tier 1/rwa) has 3,692 observations with an average of $24.31 \%$ for Islamic banks and $16.81 \%$ for conventional banks (well above the minimum $4 \%$ capital requirement proposed by the BCBS). Non-risk based capital measures have almost three times as many observations. For instance, the ratio of common equity to total assets has a total of 8,398 observations with an average value of $20.96 \%$ for Islamic banks and $13.62 \%$ for conventional banks. Table 1.B breaks down the number of observations for the three risk-based capital ratios and traditional capital ratios over time. The number of missing observations between the risk-based capital variables and the common equity to assets ratio stands out. In addition, we can observe that the disclosure of capital ratios increases over time, which reflects bank engagement in adopting the BCBS requirements of disclosing capital information.

\section{INSERT TABLE [1] AROUND HERE}

\subsection{The association between capital, bank profitability, and efficiency: An overview}

To consider the effect of capital on bank profitability and efficiency, we regress our profitability and productive efficiency ratios on a vector of eight capital ratios that include Basel risk- and non-risk based capital ratios in addition to traditional capital measures, while controlling for bank level, country, and year fixed effects. Following Demirgüç-Kunt et al. (2013) and Anginer and Demirgüç-Kunt (2014), we use the OLS regression model in Eq. (1). The results are presented in Table (2) for the profitability models and the efficiency models. ${ }^{15}$

The findings ${ }^{16}$ suggest that risk based and non-risk based capital ratios have a positive impact on the performance of both Islamic and conventional banks. However, we find that Tier 2 ratios have a positive but marginal effect on the profitability of conventional banks while they have no significant effect on the profitability and efficiency of Islamic banks. Finally, traditional capital indicators appear to have a strong positive association with bank profitability and efficiency for both banking systems.

\footnotetext{
${ }^{15}$ We also run regressions by separating Islamic banks from conventional banks and obtain same results. The results are available upon request.

${ }^{16}$ We do not report control variables in Table (2) and Table (3) to save space. Tables with all control variables and explanations are available upon request.
} 
The reason for choosing several capital ratios and examining their impact on bank performance is that the choice of variables might influence the results (Bitar et al., 2016; Bitar et al., 2018). For instance, Haldane (2012) finds that simple non-risk based capital measures outperform risk based capital measures when studying the association between capital and bank failure and calls for simplifying banking regulation. This is also supported by Blum (2008) and Dermine (2015) who suggest a risk independent leverage ratio as a complementary tool to capital ratios based on riskweighted-assets. Both studies argue that the Basel risk weighting approach is ineffective in dealing with complex financial products such as CDS contracts that allow banks to extend their leverage without any limits. Finally, Arnold et al. (2012) argue that regulators need to distinguish between good quality capital (e.g. the common equity Tier 1 capital ratio) and capital-like ratios (or debt ratios; e.g. the Tier 2 capital ratio). They explain that more capital is good but it is important to understand that some capital is better than other capital. Our results suggest that good quality capital such as Tier1, common equity, and tangible equity have a better effect on the profitability and efficiency of Islamic and conventional banks than capital-like ratios such as Tier 2, thus confirming Arnold et al. (2012)'s findings. The results confirm Anginer et al.'s (2014) and Demirgüç-Kunt et al.'s (2013) concerns about the composition of Tier 2 capital and how it may be the reason behind the ineffectiveness of capital ratios in absorbing losses during the subprime crisis. Tier 2 capital includes hybrid capital instruments and subordinated debt and is thus less reliable than tier 1 capital. Our findings are in line with the new BCBS guidelines, i.e. Basel III, that require banks to increase their Tier 1 capital ratio to $6 \%$ and maintain a constant Tier 2 capital ratio of only $2 \%$.

Except for the Tier 2 ratios, all capital ratios confirm the public interest and moral hazard hypotheses, suggesting a positive association between capital and bank profitability/efficiency (Barth et al., 2013; Bitar et al., 2016; Bitar et al., 2018) for both Islamic and conventional banks, thus supporting hypotheses H.1 and H.2. Our results can be interpreted as follows. First, higher capital ratios decrease moral hazard in shareholders' behavior as a response to a more skin in the game policy. It also diminishes bank managers' appetite to engage in riskier activities. Second, a strong capital structure provides strength to banks, especially in developing countries. Well capitalized banks better withstand financial crisis, political instability, and severe economic conditions. These banks have lower concerns of going bankrupt and a lower funding cost than less capitalized banks that have higher leverage, riskier portfolios and higher borrowing costs. Third, 
better regulation and supervision in the form of higher capital measures create incentives for banks to have better risk management and wiser decisions regarding lending and investment decisions and this does not exclude Islamic banks. Ultimately, these results can be reflected in allocating resources in a more efficient way, resulting in higher profitability and better bank performance.

\section{INSERT TABLE [2] AROUND HERE}

The findings also suggest that the impact of capital ratios is more pronounced for conventional than Islamic banks, thus supporting hypothesis H.3 although the F-test (Wald) for the degree of significance between regulatory coefficients of Islamic and conventional banks is not always significant, especially for the efficiency models. These findings can be explained by several factors. First, depending on the countries in which they are located, Islamic banks either use BCBS as a reference to compute their capital ratios, or employ IFSB principles and adapt BCBS to their specific business model. Applying BCBS requirements for Islamic banks without considering their particularities may reduce the intended effect of capital ratios. Second, Islamic banks lack the experience and expertise regarding the standardization and harmonization of their regulatory requirements and supervisory authorities. Finally, Islamic banks are constrained by the Islamic law and thus cannot benefit from several debt and collateral instruments - incorporated in Tier 2 compared to their conventional peers, which can be translated into a negative or non-significant impact on their performance.

\subsection{The role of bank size and too-big-to-fail banks}

To test the impact of capital ratios on the performance of larger banks and too big to fail banks, we include two variables by interacting bank size (size) - using the logarithm of total assets - and a too big to fail dummy (tbtf) - a dummy variable that equals 1 if size > upper quantile (Q75) and 0 otherwise - with our capital ratios. To do this, we use the following regression equation:

$$
\begin{aligned}
\mathrm{f}(\mathrm{PROF} 1 \& 2, \mathrm{EFF} 1 \& 2)_{\mathrm{ijt}}= & \alpha+\varphi \times \text { bank_control }_{\mathrm{ijt}}+\beta_{2} \times \mathrm{IBDV} \times \text { Capital_ra }_{\mathrm{ijt}} \times(\text { size } / \text { tbtf }) \\
& +\beta_{2} \times \mathrm{CBDV} \times \text { Capital_ra }_{\mathrm{ijt}} \times(\text { size } / \text { tbtf })+\mathrm{C}_{\mathrm{c}}+\mathrm{Y}_{\mathrm{Y}}+\varepsilon_{\mathrm{i}}
\end{aligned}
$$

Table (3) Panel A reports the results for bank size while Panel B provides the results for too big to fail banks. The findings suggest that larger banks with higher capital ratios are more profitable 
and more efficient (Panel A). The results persist when employing the too big to fail dummy for efficiency models (Panel B) but they are less effective for profitability models especially for Islamic banks. Anginer and Demirgüç-Kunt (2014) argue that larger banks exist in several markets in different countries, engage in non-traditional activities, and tend to have higher profits and thus higher retained earnings in their capital buffer. Accordingly, capital ratios should be positively associated with bank profitability and efficiency. In addition, holding higher capital ratios encourages bank managers to adopt better banking and risk management practices (Bitar et al., 2018), which translate into a lower risk of financial crises, better supervision and monitoring (Barth et al., 2013), and thus higher efficiency scores. However, bigger banks might be more sensitive to capital because they will invest less in riskier portfolios and require more supervision and monitoring. The same rationale applies for Islamic banks. As they become bigger, challenges in term of risk management, investment choices, and Sharia'a compliance will become stronger. Accordingly, holding higher capital buffers can become a barrier against investments rather than an insurance policy, which could explain the reduced impact on the profitability ratios.

\section{INSERT TABLE [3] AROUND HERE}

\subsection{Highly capitalized banks}

To further assess the motives behind holding higher capital ratios and their impact on bank performance, we focus on excessively capitalized banks. Berger et al. (2008) provides three arguments for holding excess capital. First, higher capital ratios reflect higher retained earnings as a precautionary policy against any future equity shortages. ${ }^{17}$ Second, banks are more sensitive to factors such a as earnings volatility, depositors, charter values and regulatory policies (e.g. too-bigto-fail) which create incentives for bank managers to adapt their capital ratios according to these factors. Finally, banks that plan to have future mergers prefer to maintain higher capital buffers to ensure regulators' acceptance. As for the impact on bank performance, the literature shows that higher ratios ameliorate bank profitability and efficiency because they create an incentive for bank managers to avoid risk, ameliorate monitoring and supervision of lending activities, lower bank costs

\footnotetext{
${ }^{17}$ Barajas et al. (2015) argue that there are four factors in corporate finance that make raising equity costly: insufficient information about bank loan portfolios, favorable conditions regarding the tax treatment of dividends, the existence of a too-big-to-fail policy, and, the use of a deposit insurance scheme. According to the authors, these factors put constraints on Modigliani and Miller's (for more details, see Chami et al. (2001)) theorem that posits that bank capital structure is irrelevant to its value and thus financing bank operations should not be constrained by a bank's equity.
} 
(e.g. by raising capital in stress situations) and thus improve bank performance. We define excess regulatory capital as the value that exceeds the minimum capital requirements explicitly determined by the BCBS. The minimum level is given as a $4 \%$ Tier 1 (tier 1/rwa) and an $8 \%$ capital adequacy ratio (total capital/rwa) for adequately capitalized banks and a $6 \%$ Tier 1 and a 10\% capital adequacy ratio for well capitalized banks. Table (4) reports the results following three distinguished definitions of excess capital. ${ }^{18}$ Panel A and Panel B define excess capital as the difference between the actual capital ratios disclosed by banks in their annual report and the minimum level required by banking regulatory authorities (i.e. the BCBS). Panel A employs a minimum value of $4 \%$ for Tier 1 and $8 \%$ for capital adequacy using the international BCBS standards while Panel B employs a minimum value of $6 \%$ for Tier 1 and 10\% for capital adequacy for well capitalized banks. Finally, Panel C defines excess capital using a dummy that equals 1 when a capital ratio exceeds its upper quantile (Q75) and 0 otherwise. Our findings show very consistent results. Excess risk-based capital ratios as defined in Panel A, Panel B, and Panel C are positively associated with banks' profitability and efficiency although the results are less significant for Islamic banks, in particular in the profitability models. We conclude that adequately capitalized banks, well capitalized banks, and highly capitalized banks are more likely to have a positive effect on bank performance which reflects good monitoring and supervision and good risk management, thus supporting the BCBS argument about capital ratios as a good determinant of bank performance. The findings also confirm hypotheses $\mathrm{H} 1$, $\mathrm{H} 2$, and $\mathrm{H} 3$ although the F-test (Wald) for the degree of significance between regulatory coefficients of Islamic and conventional banks is not always significant.

\section{INSERT TABLE [4] AROUND HERE}

\subsection{Robustness tests ${ }^{19}:$ Endogeneity concerns and other estimation techniques}

Despite the differences in views regarding the importance of using lagged (e.g. DemirgüçKunt et al., 2013; Anginer and Demirgüç-Kunt, 2014) versus non-lagged (Chortareasa et al., 2012; Barth et al. 2013) independent variables when examining the impact of banking regulation, we

\footnotetext{
${ }^{18} \mathrm{We}$ only present results for the Basel capital ratios. In unreported regressions, we perform similar analyses for other capital ratios and obtain very consistent results. These results are available upon request.

19 Additional information and tests on the effects of Basel versus IFSB guidelines, institutional environment, and subsamples on bank performance are available on the following website: https://business.missouri.edu/peopledirectory/kuntara-pukthuanthong.
} 
hypothesize that regulatory ratios might take more than one year to show any pronounced effect. In addition, a one-year lag in the independent variables reduces any concerns about endogeneity. ${ }^{20}$ Therefore, we lag our capital ratios by one year to examine the robustness of our results. Our results, reported in Table (5), are very similar to the results we obtain with our main and alternative performance measures, thus confirming our earlier findings.

\section{INSERT TABLE [5] AROUND HERE}

To further examine the interaction between capital ratios and the performance of conventional and Islamic banks, we extend Eq. (1) and perform truncated regressions in a first step, a first difference estimation in a second step, and conditional quantile regressions in as second step. Barth et al. (2013) explain that efficiency scores are truncated below zero and above one hundred. Thus, the error term has double truncation. According to Simar and Wilson (2007), applying a truncated regression permits valid inferences. We use standard maximum likelihood estimation with heteroscedasticity robust standards errors clustered by banks to allow for residuals to be correlated across time and within banks. Our results, reported in Table (6), Panel A, are more pronounced than our earlier findings. ${ }^{21}$

Barth et al. (2013) suggest that it would be interesting to explore how banks' efficiency reacts to changes in regulatory reforms. Another reason for studying changes in capital ratios is that Islamic banks are often more capitalized than their conventional peers. Therefore, it is important to study the year-to-year changes for different capital ratios in addition to the effect of their absolute values on profitability and efficiency. To accomplish this, we employ a first-difference estimation with year-to-year changes for all dependent and independent variables. We lose several bank-year observations because of the first-differentiation estimation. As a result, the final sample contains observations for fourteen out of fifteen years. The findings are presented in Table (6), Panel B, and show that an increase in banks' capital ratios have a positive and significant effect on the profitability and the efficiency changes for both bank types although the effect is more pronounced for

\footnotetext{
${ }^{20}$ We also apply an Instrumental Variables (IV) approach using 2-Stage Least Squares regressions (2SLS) on the entire sample (without separating it into Islamic and conventional banks). As instruments, we employ Overall Economic Freedom and the World Governance Indexes in the profitability and efficiency models, respectively. The results provide additional support for our earlier findings and suggest that they are not driven by endogeneity.

${ }^{21}$ In other robustness tests, we use two alternative profitability and efficiency measures in a first step and four alternative capital measures in a second step. The results are qualitatively and quantitatively similar to the results presented here and are available upon request.
} 
conventional than for Islamic banks. The results suggest that changes in bank capital for regulatory reasons (e.g., different capital guidelines, changes in the institutional environment) have a direct positive effect on bank profitability and efficiency.

\section{INSERT TABLE [6] AROUND HERE}

Finally, we employ a conditional quantile regression ${ }^{22}$ because it allows for heterogeneous solutions to our capital proxies by conditioning on bank profitability and efficiency (less profitable/less efficient vs. highly profitable/highly efficient).

Figures 1 and 2 plot the estimates for our quantile and least squares regressions for all capital ratios specified in the profitability (PROF1) and efficiency (EFF1) models, respectively. ${ }^{23}$ For each covariate, we plot the quantile regression estimates for the capital ratios as a function of quantiles ranging from 0.05 to 0.95 shown as a solid curve. The shaded grey band illustrates the conventional 90 percent confidence interval, estimated using a bootstrapping technique. The long dashed line represents the OLS estimate and the two dotted lines characterize the confidence band.

Risk- and non-risk based capital measures in addition to traditional capital ratios show that banks with higher capital ratios have higher profitability and efficiency. The findings are more important in magnitude as both performance measures move up towards the upper quantile. Our results can be explained by the fact that more profitable banks tend to hold higher capital buffers as retained earnings (Ariff and Can, 2008). We also note that capital-like ratios (Tier 2 ratios) derived from both risk and non-risk-based measures do not show the same pattern compared to other capital ratios; rather they show a destabilizing effect. Our results confirm the findings of Arnold et al. (2012), Bitar et al., (2016), and Bitar et al. (2018), who suggest that the use of some capital such as Tier 1 or common equity is better than other capital such as Tier 2 capital.

\section{INSERT FIGURES [1 \& 2] AROUND HERE}

\footnotetext{
${ }^{22}$ Quantile regression results are also robust for outliers and distributions with heavy tails. In addition, quantile regressions avoid the restrictive assumption that the error terms are identically distributed at all points of the conditional distribution.

${ }^{23}$ The quantile regression results confirm our earlier findings. We do not report the respective tables to save space; however, they are available from the authors upon request.
} 


\section{Conclusion}

This is the first study that explores the relation between BCBS capital guidelines and the profitability and efficiency of Islamic and conventional banks. In contrast to most studies that use traditional capital ratios, we employ various forms of capital ratios in addition to several profitability and efficiency measures. Our results suggest that: First, various forms of capital positively affect the profitability and efficiency of both Islamic banks and conventional banks, thus supporting the public interest and the moral hazard hypotheses. Second, capital ratios have a more pronounced impact on the operating performance of conventional banks than for Islamic banks. Third, our results appear to be affected by larger banks, too-big to-fail banks, and highly capitalized banks. Finally, the findings are robust to alternative performance and capital measures, additional control variables, and other estimation techniques.

There are several limitations to our study but three are worth of note. First, there is no prior theoretical or empirical literature that compares the impact of banking regulations in terms of capital ratios on the profitability and efficiency of Islamic banks. While the lack of prior research work makes the contribution of our study unique, it also means that there is no widely accepted standard to estimate the impact of BCBS/IFSB capital ratios on this type of institutions. Second, our sample lacks bank level observations especially for risk-based capital ratios such as Tier 1/rwa and total capital/rwa for both Islamic and conventional banks. Third, we are unable to use market indicators such as stock returns because of a lack of bank observations. Once more data becomes available, future studies should be able to examine the relations between capital and bank performance using reasonably large samples to conduct regressions.

Our work is important given the renewed focus on the regulation of conventional banks. It also poses several questions about the regulatory framework for Islamic banks. Indeed, future work should determine an appropriate regulatory framework for Islamic banks. Islamic regulatory organizations should use Islamic financial principles and concepts to create their own set of ratios rather than imitating the Basel framework. However, we do not call upon Islamic banks to escape the BCBS framework, rather we believe that the existence of IFSB capital guidelines is welcomed and can serve as a cornerstone for more detailed capital guidelines that not only consider the particularities but also the heterogeneity of Islamic banks across countries. 


\section{References}

Abedifar, P., Molyneux, P., Tarazi, A., 2013. Risk in Islamic banking. Review of Finance 17, 20352096.

Altunbas, Y., Carbo, S., Gardner, E., Molyneux, P., 2007. Examining the relationship between capital, risk and efficiency in European banking. European Financial Management 13, 49-70.

Anginer, D., Demirgüç-Kunt, A., 2014. Bank capital and systemic stability. Policy Research Working Paper No. 6948, The World Bank, Washington, DC.

Anginer, D., Demirgüç-Kunt, A., and Zhu, M., 2014. How does bank competition affect bank systemic risk? Journal of Financial Intermediation 23, 1-26.

Arnold, B., Borio, C., Ellis, L., Moshirian, F., 2012. Systemic risk, macroprudential policy framework, monitoring financial systems and the evolution of capital adequacy. Journal of Banking \& Finance 36, 3125-3132.

Ariff, M., Can, L., 2008. Cost and profit efficiency of Chinese banks: A non-parametric analysis. China Economic Review 19, 260-273.

Ayadi, R., Ben Naceur, S., Casu, B., Quinn, B., 2015. Does Basel compliance matter for bank performance. Working paper WP/15/100, International Monetary Fund, Washington, DC.

Barajas, A., Cosimano, T., Hakura, D., Roelands, S. 2015. The role of bank capital in bank holding companies' decisions. Working paper WP/15/57, International Monetary Fund, Washington, DC.

Barth, J., Lin, C., Ma, Y., Seade, J., Song, F. 2013. Do bank regulation, supervision and monitoring enhance or impede bank efficiency? Journal of Banking \& Finance 37, 2879-2892.

Beck, T., Demirgüç-Kunt, A., and Merrouche, O. 2013. Islamic vs. conventional banking: Business model, efficiency and stability. Journal of Banking \& Finance 37, 433-447.

Berger, A.N., DeYoung, R., Flannery, M.J., Lee, D., Öztekin, Ö. 2008. How do large banking organizations manage their capital ratios? Journal of Financial Services Research 34, 123-149.

Berger, A.N., Di Patti, E. 2006. Capital structure and firm performance: A new approach to testing agency theory and an application to the banking industry. Journal of Banking \& Finance 30, $1065-1102$.

Bitar, M., Saad, W., and Benlemlih, M. 2016. Bank risk and performance in the MENA region: the importance of capital requirements, Economic Systems 40, 398-421.

Bitar, M., Hassan, M.K., Walker, T. 2017. Political systems and the financial soundness of Islamic banks, Journal of financial stability 31, 18-44.

Bitar, M., Hassan, M.K., Walker, T. 2018. The effect of capital ratios on the risk, efficiency and profitability of banks: Evidence from OECD countries, Journal of International Financial Markets, Institutions and Money 53, 227-262.

Blum, J. M. 2008. Why Basel II may need a leverage ratio restriction. Journal of Banking \& Finance $32,1699-1707$. 
Carvallo, O., Kasman, A., 2005. Cost efficiency in Latin American and Caribbean banking systems. Journal of International Financial Markets Institutions and Money 15, 55-72.

Cathcart, L., El-Jahel, L., Jabbour, R., 2015. Can regulators allow banks to set their own capital ratios? Journal of Banking \& Finance 53, 112-123.

Chami, R., Cosimano, T., Fullenkamp, C., 2001. Capital trading, stock trading and the inflation tax on equity. Review of Economic Dynamics 4, 575-606.

Chortareasa, G.E., Girardoneb, C., Ventouric, A., 2012. Bank supervision, regulation, and efficiency: Evidence from the European Union. Journal of Financial Stability 8, 292-302.

Demirgüç-Kunt, A., Detragiache, E., Merrouche, O., 2013. Bank capital: Lessons from the financial crisis. Journal of Money, Credit and Banking 45, 1147-1164.

Demirgüç-Kunt, A., Klapper, L., and Randall, D. 2013. Islamic finance and financial inclusion: Measuring use and demand for formal financial services among Muslim adults. Policy Research, Working Paper, No. 6642, The World Bank., Washington, DC.

Dermine, J., 2015. Basel III leverage ratio requirement and the probability of bank runs. Journal of Banking \& Finance 53, 266-277.

Drake, L. and Hall, M. J. B. 2003. Efficiency in Japanese banking: An empirical analysis. Journal of Banking \& Finance 27, 891-917.

Ernst \& Young, 2014. Global Islamic Banking Knowledge Center.

Fiordelisi, F., Marques-Ibanez, D., Molyneux, P., 2011. Efficiency and risk in European banking. Journal of Banking \& Finance 35, 1315-1326.

Gheeraert, L., 2014. Does Islamic finance spur banking sector development? Journal of Economic Behavior \& Organization 103, S4-S20.

Goddard, J., Liu, H., Molyneux, P., Wilson, J.O.S., 2013. Do bank profits converge? European Financial Management 19, 345-365.

Haldane, A.G., 2012. The Dog and the Frisbee. Bank of England, United Kingdom.

IBRD, 2014. Global financial development report: Financial inclusion. International Bank for Reconstruction and Development, The World Bank, Washington, DC.

Imam, P., Kpodar, K., 2015. Is Islamic banking good for growth? Working Paper WP/15/81, International Monetary Fund, Washington, DC.

Jawadi, F, Cheffou, A, and Jawadi, N. 2016a. Do Islamic and conventional banks really differ? A panel data statistical analysis, Open Economies Review 27, 293-302.

Jawadi, F, Cheffou, A, Jawadi, N., and Louhichi, W. 2016b. On the reputation of Islamic banks: A panel data qualitative econometrics analysis, Open Economies Review 27, 987-998.

Johnes, J., Izzeldin, M., and Pappas, V. 2014. A comparison of performance of Islamic and conventional banks 2004 to 2009, Journal of Economic Behavior \& Organization 103, 93-107.

Klomp, J., De Haan, J., 2012. Banking risk and regulation: does one solution fit all? Journal of Banking and Finance 36, 3197-3212. 
Klomp, J., De Haan, J., 2014. Bank regulation, the quality of institutions, and banking risk in emerging and developing countries: an empirical analysis. Emerging Market, Finance, and Trade 50, 19-40.

Lee, C., Hsieh, M., 2013. The impact of capital on profitability and risk in Asian banking. Journal of International Money and Finance 32, 251-281.

López-Mejía, A., Aljabrin, S., Awad, R., Norat, M., Song, I., 2014. Regulation and supervision of Islamic banks. Working paper WP/14/219, International Monetary Fund, Washington, DC.

Masciandaro, D., 2011. The Handbook of Central Banking, Financial Regulation and Supervision after the Crisis, (con S. Eijffinger), Edward Elgar, 2011.

Mollah, S., and Zaman, M., 2015. Shari'ah supervision, corporate governance, and performance: Conventional vs. Islamic banks, Journal of Banking \& Finance 58, 418-435.

Park, K.H., Weber, W.L., 2006. Profitability of Korean banks: Test of market structure versus efficient structure. Journal of Economics and Business 58, 222-239.

Pasiouras, F., Tanna, S., Zopounidis, C., 2009. Banking regulations, cost and profit efficiency: Cross-country evidence. International Review of Financial Analysis 18, 294-302.

Pattison, J.C., 2006. International financial cooperation and the number of adherents: The Basel committee and capital regulation. Open Economic Review 17, 443-458.

Rosman, R., Abd Wahab, N., Zainol, Z., 2014. Efficiency of Islamic banks during the financial crisis: An analysis of Middle Eastern and Asian countries. Pacific-Basin Finance Journal 28, 76-90.

Shehzad, C.T., De Haan, J., 2015. Supervisory powers and bank risk taking. Journal of International Financial Markets, Institutions, and Money 39, 15-24.

Simar, L., Wilson, p., 2007. Estimation and inference in two-stage, semi-parametric models of production processes. Journal of Econometrics 136, 31-64.

Song, I., Oosthuizem, C., 2014. Islamic banking regulation and supervision: Survey results and challenges. Working paper WP/14/220, International Monetary Fund, Washington, DC. 
Tables

Table 1.A

Descriptive statistics

\begin{tabular}{|c|c|c|c|c|c|c|c|c|c|}
\hline Label & $\mathrm{N}$ & Mean & Median & Std Dev. & Min. & Max. & $\begin{array}{l}\text { Islamic } \\
\text { banks (IBs) } \\
\text { Mean }\end{array}$ & $\begin{array}{l}\text { Conventional } \\
\text { banks (CBs) } \\
\text { Mean }\end{array}$ & $\begin{array}{l}\text { Two-sample } \\
\text { t-test } \\
(\mathrm{CB}-\mathrm{IB})\end{array}$ \\
\hline \multicolumn{10}{|l|}{ Performance variables } \\
\hline PROF 2 & 6717 & 1.55 & 1.41 & 2.52 & -9.05 & 17.46 & 1.88 & 1.48 & $-3.64 * * *$ \\
\hline EFF 1 & 6635 & 49.56 & 44.56 & 25.48 & 0 & 100 & 52.36 & 49.06 & $-3.57 * * *$ \\
\hline EFF 2 & 5200 & 63.11 & 59.92 & 24.01 & 0 & 100 & 67 & 62.52 & $-4.4 * * *$ \\
\hline \multicolumn{10}{|c|}{ Alternative performance variables } \\
\hline NIMP & 8195 & 3.99 & 3.39 & 3.24 & -6.27 & 28.23 & 4.27 & 3.94 & $-2.5 * *$ \\
\hline FEEAAP & 6669 & 1.16 & 0.73 & 1.42 & -0.23 & 13.32 & 1.26 & 1.14 & $-1.91 *$ \\
\hline EFF3 & 6635 & 56.73 & 52.12 & 26 & 0 & 100 & 75.3 & 53.38 & $-25.0 * * *$ \\
\hline EFF4 & 5200 & 69.38 & 67.36 & 23.17 & 0 & 100 & 86.37 & 66.84 & $-23.43 * * *$ \\
\hline \multicolumn{10}{|l|}{ Main variables } \\
\hline Tier 1/rwa & 3692 & 18.34 & 14.58 & 12.03 & 7.51 & 79.8 & 24.31 & 16.81 & $-10.55 * * *$ \\
\hline Tier 2/rwa & 3634 & 2.06 & 1.38 & 1.96 & 0 & 8.7 & 1.35 & 2.24 & $13.11 * * *$ \\
\hline Total capital/rwa & 4988 & 21.23 & 19.97 & 12.61 & 9.43 & 86 & 26.23 & 20.2 & $-8.53 * * *$ \\
\hline Tier $2 /$ ta & 3530 & 1.44 & 0.89 & 1.69 & 0 & 11.26 & 0.95 & 1.53 & $10.2 * * *$ \\
\hline Total capital/ta & 3818 & 13.33 & 10.83 & 9.66 & 3.57 & 75.57 & 18.54 & 12.34 & $-8.24 * * *$ \\
\hline Common equity/ta & 8398 & 14.82 & 10.3 & 14.45 & 2.64 & 82.42 & 20.96 & 13.62 & $-12.44 * * *$ \\
\hline Tangible equity/ta & 8399 & 14.96 & 10.53 & 14.53 & 2.81 & 84.4 & 21.34 & 13.71 & $-12.67 * * *$ \\
\hline \multicolumn{10}{|l|}{ Control variables } \\
\hline Size & 8399 & 13.95 & 13.85 & 2.02 & 9.69 & 19.89 & 13.74 & 13.99 & $4.64 * * *$ \\
\hline Growth assets & 7647 & 18.26 & 12.9 & 30.37 & -44.71 & 220.18 & 27.04 & 16.59 & $-9.44 * * *$ \\
\hline Net loans/ta & 8280 & 48.69 & 50.83 & 22.95 & 0.03 & 98.85 & 47.78 & 48.86 & $1.48 * * *$ \\
\hline Fixed assets/ta & 8139 & 1.99 & 1.22 & 2.44 & 0.002 & 17.23 & 2.75 & 1.85 & $-9.9 * * *$ \\
\hline Non-operating income & 8193 & 63.07 & 66.8 & 23.37 & -21.21 & 97.85 & 58.34 & 64.00 & $6.63 * * *$ \\
\hline
\end{tabular}

Table 1.B

Number of banks and years covered in the sample

\begin{tabular}{lll|ll|ll|ll}
\hline \multicolumn{3}{l|}{ Tier 1/rwa } & \multicolumn{2}{c|}{ Tier 2/rwa } & \multicolumn{2}{c|}{ Total capital/rwa } & \multicolumn{2}{c}{ Common equity/ta } \\
\hline Year & \# CBs & \# IBs & \# CBs & \# IBs & \# CBs & \# IBs & \# CBs & \# IBs \\
\hline 1999 & 45 & 2 & 43 & 2 & 139 & 11 & 377 & 44 \\
2000 & 50 & 3 & 48 & 3 & 154 & 12 & 394 & 48 \\
2001 & 57 & 4 & 57 & 4 & 148 & 13 & 359 & 47 \\
2002 & 77 & 7 & 76 & 7 & 171 & 18 & 371 & 57 \\
2003 & 101 & 16 & 101 & 15 & 185 & 22 & 378 & 60 \\
2004 & 137 & 24 & 136 & 23 & 210 & 26 & 421 & 60 \\
2005 & 168 & 30 & 165 & 28 & 246 & 31 & 469 & 79 \\
2006 & 216 & 49 & 213 & 47 & 283 & 53 & 485 & 90 \\
2007 & 259 & 73 & 256 & 71 & 321 & 74 & 499 & 108 \\
2008 & 282 & 85 & 279 & 84 & 331 & 94 & 508 & 123 \\
2009 & 310 & 95 & 306 & 95 & 358 & 100 & 522 & 131 \\
2010 & 310 & 95 & 304 & 92 & 368 & 100 & 542 & 133 \\
2011 & 302 & 93 & 298 & 91 & 398 & 105 & 569 & 139 \\
2012 & 306 & 88 & 302 & 87 & 420 & 101 & 590 & 139 \\
2013 & 319 & 89 & 313 & 88 & 398 & 98 & 540 & 116 \\
\hline
\end{tabular}


Table 2

The effect of capital on bank profitability and efficiency: Islamic vs. conventional banks

\begin{tabular}{|c|c|c|c|c|c|c|c|c|c|c|c|c|c|c|c|c|}
\hline \multirow[t]{2}{*}{ Variables } & \multicolumn{4}{|l|}{ PROF1 } & \multicolumn{4}{|l|}{ PROF2 } & \multicolumn{4}{|l|}{ EFF1 } & \multicolumn{4}{|l|}{ EFF2 } \\
\hline & Coef. & $\mathrm{N}$ & F-test & $\mathrm{R}^{2}$ & Coef. & $\mathrm{N}$ & F-test & $\mathrm{R}^{2}$ & Coef. & $\mathrm{N}$ & F-test & $\mathrm{R}^{2}$ & Coef. & $\mathrm{N}$ & F-test & $\mathrm{R}^{2}$ \\
\hline $\begin{array}{l}\text { Tier 1/rwaxIBDV } \\
\text { Tier 1/rwaxCBDV }\end{array}$ & $\begin{array}{l}0.027 * \\
(0.015) \\
0.057 * * * \\
(0.01)\end{array}$ & 3261 & $7.69^{* * * *}$ & 0.227 & $\begin{array}{l}0.043 * * * \\
(0.015) \\
0.06 * * * \\
(0.011)\end{array}$ & 2685 & 2.47 & 0.274 & $\begin{array}{l}0.4 * * * \\
(0.074) \\
0.509 * * * \\
(0.081)\end{array}$ & 2456 & 0.182 & 0.632 & $\begin{array}{l}0.518 * * * \\
(0.098) \\
0.734 * * * \\
(0.082)\end{array}$ & 2149 & $5.57 * *$ & 0.562 \\
\hline $\begin{array}{l}\text { Tier 2/rwaxIBDV } \\
\text { Tier 2/rwaxCBDV }\end{array}$ & $\begin{array}{l}-0.035 \\
(0.076) \\
-0.003 \\
(0.029)\end{array}$ & 3213 & 0.19 & 0.186 & $\begin{array}{l}0.018 \\
(0.087) \\
-0.029 \\
(0.036)\end{array}$ & 2640 & 0.30 & 0.232 & $\begin{array}{l}-1.206 * * \\
(0.517) \\
-0.16 \\
(0.244)\end{array}$ & 2411 & $3.71 *$ & 0.617 & $\begin{array}{l}-1.197 \\
(0.730) \\
-0.453 * \\
(0.254)\end{array}$ & 2124 & 1.02 & 0.53 \\
\hline $\begin{array}{l}\text { Total capital/rwa } \\
\text { xIBDV } \\
\text { Total capital/rwa } \\
\text { xCBDV }\end{array}$ & $\begin{array}{l}0.028 * * \\
(0.012) \\
0.052 * * * \\
(0.007)\end{array}$ & 4433 & $6.21^{* *}$ & 0.199 & $\begin{array}{l}0.042 * * * \\
(0.012) \\
0.059 * * * \\
(0.009)\end{array}$ & 3808 & $2.98^{*}$ & 0.238 & $\begin{array}{l}0.416 * * * \\
(0.059) \\
0.504 * * * \\
(0.064)\end{array}$ & 3571 & 2.02 & 0.607 & $\begin{array}{l}0.487 * * * \\
(0.079) \\
0.617 * * * \\
(0.065)\end{array}$ & 3061 & $3.16^{*}$ & 0.56 \\
\hline $\begin{array}{l}\text { Tier } 1 / \text { ta xIBDV } \\
\text { Tier } 1 / \text { ta xCBDV }\end{array}$ & $\begin{array}{l}0.045^{*} \\
(0.026) \\
0.088^{* * *} \\
(0.016)\end{array}$ & 3312 & $5.78^{* *}$ & 0.223 & $\begin{array}{l}0.067 * * * \\
(0.022) \\
0.092 * * * \\
(0.017)\end{array}$ & 2720 & 2.12 & 0.283 & $\begin{array}{l}0.59 * * * \\
(0.088) \\
0.912 * * * \\
(0.134)\end{array}$ & 2466 & $8.55^{* * * *}$ & 0.635 & $\begin{array}{l}0.644 * * * \\
(0.148) \\
1.146 * * * \\
(0.146)\end{array}$ & 2133 & $13.51 * * *$ & 0.544 \\
\hline $\begin{array}{l}\text { Tier 2/ta xIBDV } \\
\text { Tier 2/ta xCBDV }\end{array}$ & $\begin{array}{l}-0.085 \\
(0.123) \\
0.076^{* *} \\
(0.036)\end{array}$ & 3247 & 1.81 & 0.177 & $\begin{array}{l}0.069 \\
(0.143) \\
0.07 * \\
(0.041)\end{array}$ & 2658 & 0.00 & 0.227 & $\begin{array}{l}-0.751 \\
(0.817) \\
0.271 \\
(0.369)\end{array}$ & 2405 & 1.59 & 0.605 & $\begin{array}{l}-1.127 \\
(1.016) \\
-0.243 \\
(0.360)\end{array}$ & 2080 & 0.78 & 0.501 \\
\hline $\begin{array}{l}\text { Total capital/ta xIBDV } \\
\text { Total capital/ta } \\
\text { xCBDV }\end{array}$ & $\begin{array}{l}0.044 * \\
(0.0256) \\
0.083 * * * \\
(0.015)\end{array}$ & 3513 & $5.34 * *$ & 0.218 & $\begin{array}{l}0.067 * * * \\
(0.022) \\
0.092^{* * * *} \\
(0.016)\end{array}$ & 2915 & 2.50 & 0.273 & $\begin{array}{l}0.606 * * * \\
(0.092) \\
0.911 * * * \\
(0.120)\end{array}$ & 2662 & $9.98 * * *$ & 0.637 & $\begin{array}{l}0.648 * * * \\
(0.143) \\
1.047 * * * \\
(0.129)\end{array}$ & 2290 & $10.89 * * *$ & 0.55 \\
\hline $\begin{array}{l}\text { Common equity/ta } \\
\text { xIBDV } \\
\text { Common equity/ta } \\
\text { xCBDV }\end{array}$ & $\begin{array}{l}0.043 * * * \\
(0.022) \\
0.065^{* * * *} \\
(0.006)\end{array}$ & 7203 & $3.56^{*}$ & 0.181 & $\begin{array}{l}0.061 * * * \\
(0.011) \\
0.073^{* * * *} \\
(0.008)\end{array}$ & 6302 & 1.32 & 0.218 & $\begin{array}{l}0.573 * * * \\
(0.057) \\
0.655 * * * \\
(0.062)\end{array}$ & 6043 & 1.62 & 0.544 & $\begin{array}{l}0.653 * * * \\
(0.075) \\
0.752 * * * \\
(0.058)\end{array}$ & 4780 & 1.61 & 0.524 \\
\hline $\begin{array}{l}\text { Tangible equity/ta } \\
\text { xIBDV } \\
\text { Tangible equity/ta } \\
\text { xCBDV }\end{array}$ & $\begin{array}{l}0.046 * * * \\
(0.012) \\
0.069 * * * \\
(0.007)\end{array}$ & 7203 & $4.15^{* *}$ & 0.187 & $\begin{array}{l}0.062 * * * \\
(0.011) \\
0.077 * * * \\
(0.008)\end{array}$ & 6302 & 1.87 & 0.224 & $\begin{array}{l}0.572 * * * \\
(0.057) \\
0.669 * * * \\
(0.063)\end{array}$ & 6043 & 2.33 & 0.545 & $\begin{array}{l}0.656 * * * \\
(0.074) \\
0.758 * * * \\
(0.058)\end{array}$ & 4780 & 1.77 & 0.525 \\
\hline
\end{tabular}

Notes: PROF1 is the ratio of net income to three year average assets. PROF2 is the ratio of operating profit to three year average assets. EFF1 is a basic gross efficiency score model in which we do not control for the risk in bank inputs. EFF2 is a basic gross efficiency score model in which we introduce loan loss provisions to control for risk in bank inputs. The estimations are based on OLS regressions with country and year fixed effects. For expositional brevity, we only report the coefficient estimates of the interactions terms between the Islamic bank dummy variable (IBDV), the conventional bank dummy variable (CBDV), and different proxies of capital ratios. Standard errors are clustered at the bank level and are reported in parentheses below their coefficient estimates.

* denotes statistical significance at the $10 \%$ level.

$* *$ denotes statistical significance at the $5 \%$ level.

*** denotes statistical significance at the $1 \%$ level 
Table 3

Capital, bank size, and too big to fail banks

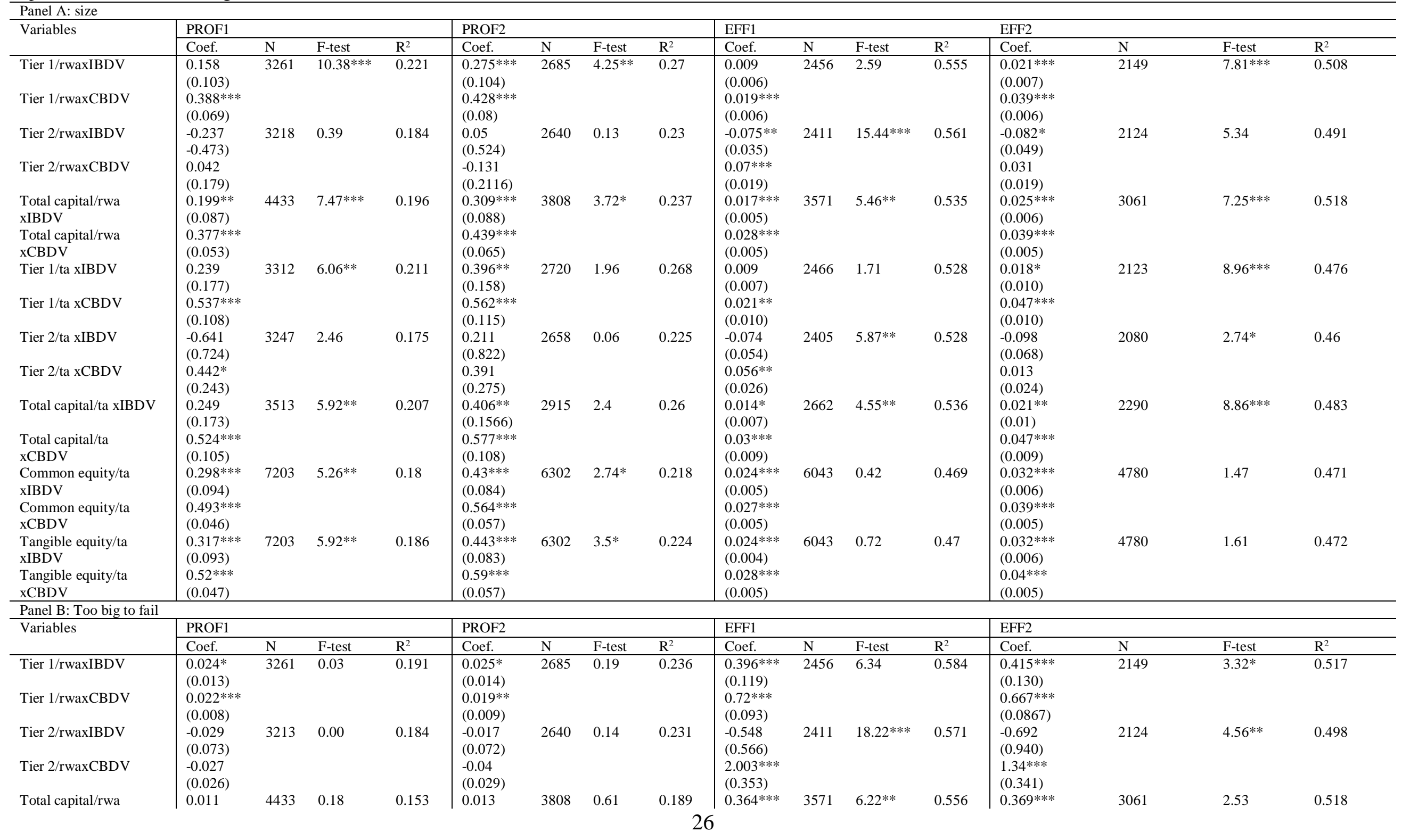




\begin{tabular}{|c|c|c|c|c|c|c|c|c|c|c|c|c|c|c|c|c|}
\hline xIBDV & $(0.011)$ & & & & $(0.013)$ & & & & $(0.109)$ & & & & $(0.121)$ & & & \\
\hline $\begin{array}{l}\text { Total capital/rwa } \\
\text { xCBDV }\end{array}$ & $\begin{array}{l}0.007 \\
(0.006)\end{array}$ & & & & $\begin{array}{l}0.003 \\
(0.007)\end{array}$ & & & & $\begin{array}{l}0.646 * * * \\
(0.072)\end{array}$ & & & & $\begin{array}{l}0.564 * * * \\
(0.067)\end{array}$ & & & \\
\hline $\begin{array}{l}\text { Tier 1/ta xIBDV } \\
\text { Tier 1/ta xCBDV }\end{array}$ & $\begin{array}{l}0.027 \\
(0.018) \\
0.022^{*} \\
(0.013)\end{array}$ & 3312 & 0.06 & 0.179 & $\begin{array}{l}0.023 \\
(0.020) \\
0.014 \\
(0.014)\end{array}$ & 2720 & 0.19 & 0.231 & $\begin{array}{l}0.551 * * * \\
(0.146) \\
0.996 * * * \\
(0.142)\end{array}$ & 2466 & $7.72 * * *$ & 0.552 & $\begin{array}{l}0.58 * * * \\
(0.155) \\
0.967 * * * \\
(0.147)\end{array}$ & 2123 & $5.12^{* * *}$ & 0.486 \\
\hline $\begin{array}{l}\text { Tier 2/ta xIBDV } \\
\text { Tier 2/ta xCBDV }\end{array}$ & $\begin{array}{l}-0.135 \\
(0.089) \\
-0.037 \\
(0.036)\end{array}$ & 3247 & 1.23 & 0.172 & $\begin{array}{l}-0.124 \\
(0.078) \\
-0.055 \\
(0.039)\end{array}$ & 2658 & 0.85 & 0.225 & $\begin{array}{l}-0.226 \\
(0.847) \\
2.377 * * * \\
(0.471)\end{array}$ & 2405 & $8.48 * * *$ & 0.537 & $\begin{array}{l}-0.702 \\
(1.229) \\
1.621 * * * \\
(0.482)\end{array}$ & 2080 & $3.53^{*}$ & 0.466 \\
\hline $\begin{array}{l}\text { Total capital/ta xIBDV } \\
\text { Total capital/ta } \\
\text { xCBDV }\end{array}$ & $\begin{array}{l}0.016 \\
(0.016) \\
0.016 \\
(0.011)\end{array}$ & 3513 & 0.00 & 0.171 & $\begin{array}{l}0.015 \\
(0.019) \\
0.012 \\
(0.012)\end{array}$ & 2915 & 0.04 & 0.216 & $\begin{array}{l}0.526 * * * \\
(0.139) \\
0.923 * * * \\
(0.115)\end{array}$ & 2662 & $6.93 * * *$ & 0.559 & $\begin{array}{l}0.529 * * * \\
(0.156) \\
0.851 * * * \\
(0.115)\end{array}$ & 2290 & $3.97 * *$ & 0.493 \\
\hline $\begin{array}{l}\text { Common equity/ta } \\
\text { xIBDV } \\
\text { Common equity/ta } \\
\text { xCBDV }\end{array}$ & $\begin{array}{l}0.019 \\
(0.017) \\
0.024 * * \\
(0.009)\end{array}$ & 7203 & 0.10 & 0.124 & $\begin{array}{l}0.017 \\
(0.016) \\
0.022^{*} \\
(0.012)\end{array}$ & 6302 & 0.09 & 0.144 & $\begin{array}{l}0.303 * * \\
(0.132) \\
0.894 * * * \\
(0.103)\end{array}$ & 6043 & $16.07 * * *$ & 0.472 & $\begin{array}{l}0.437 * * * \\
(0.127) \\
0.808 * * * \\
(0.107)\end{array}$ & 4780 & 6.51 & 0.46 \\
\hline $\begin{array}{l}\text { Tangible equity/ta } \\
\text { xIBDV } \\
\text { Tangible equity/ta } \\
\text { xCBDV }\end{array}$ & $\begin{array}{l}0.02 \\
(0.017) \\
0.024 * * * \\
(0.009)\end{array}$ & 7203 & 0.06 & 0.124 & $\begin{array}{l}0.017 \\
(0.015) \\
0.021^{*} \\
(0.012)\end{array}$ & 6302 & 0.07 & 0.144 & $\begin{array}{l}0.292 * * \\
(0.130) \\
0.869 * * * \\
(0.101)\end{array}$ & 6043 & $15.87 * * *$ & 0.472 & $\begin{array}{l}0.442 * * * \\
(0.127) \\
0.79 * * * \\
(0.107)\end{array}$ & 4780 & $5.8^{* *}$ & 0.46 \\
\hline
\end{tabular}

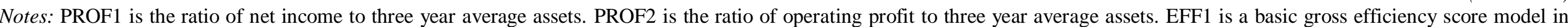

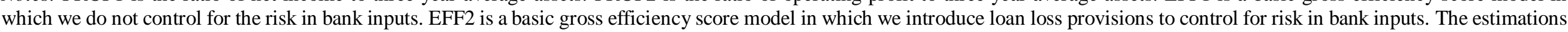

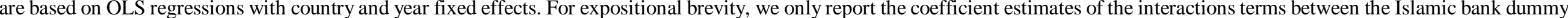

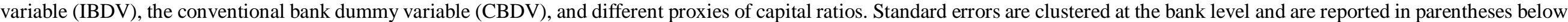
their coefficient estimates.

* denotes statistical significance at the $10 \%$ level.

** denotes statistical significance at the 5\% level.

*** denotes statistical significance at the $1 \%$ level. 
Table 4

Highly capitalized banks

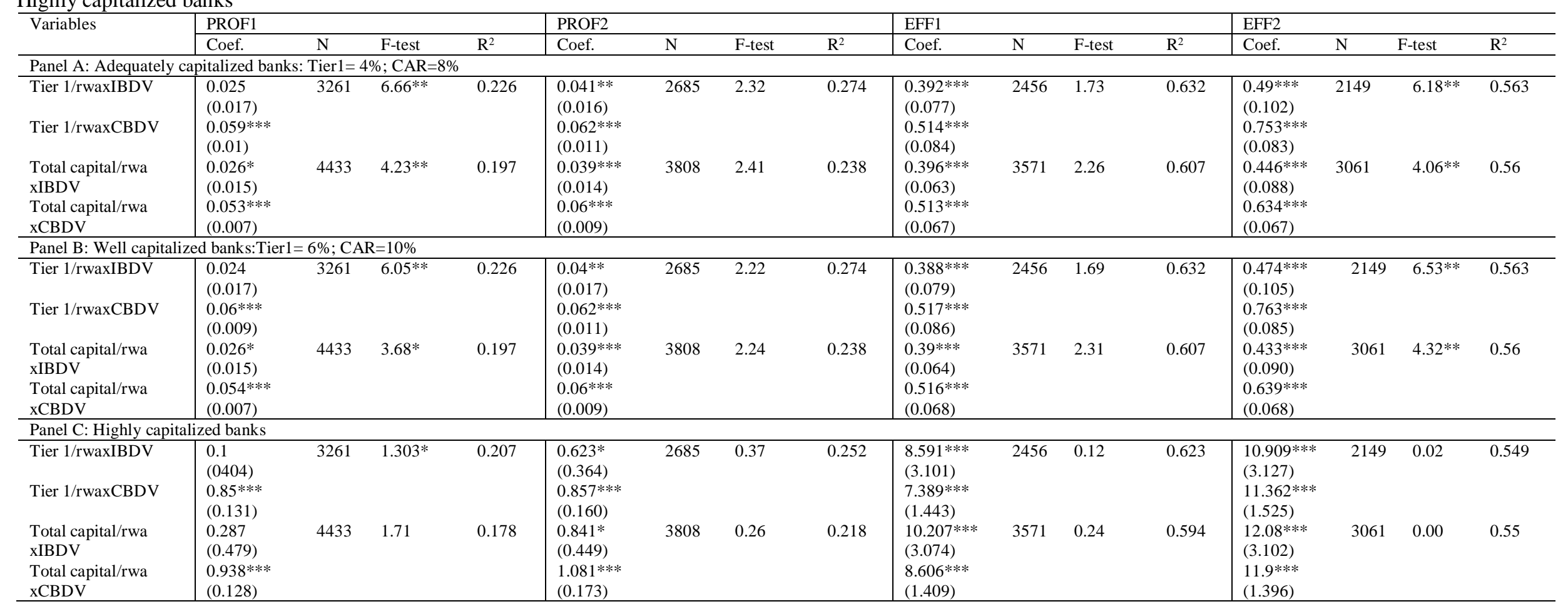

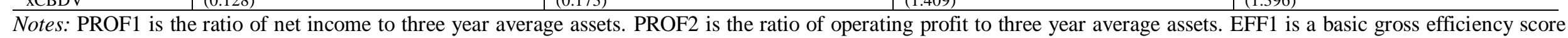
model in which we do not control for the risk in bank inputs. EFF2 is a basic gross efficiency score model in which we introduce loan loss provisions to control for risk in bank inputs. The estimations are based on OLS regressions with country and year fixed effects. For expositional brevity, we only report the coefficient estimates of the interactions

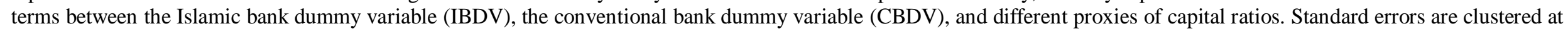
the bank level and are reported in parentheses below their coefficient estimates.

* denotes statistical significance at the $10 \%$ level.

$* *$ denotes statistical significance at the $5 \%$ level.

*** denotes statistical significance at the $1 \%$ level. 
Table 5

One year lag - controlling for possible endogeneity

\begin{tabular}{|c|c|c|c|c|c|c|c|c|c|c|c|c|c|c|c|c|}
\hline \multirow[t]{2}{*}{ Variables } & \multicolumn{4}{|l|}{ PROF1 } & \multicolumn{4}{|l|}{ PROF2 } & \multicolumn{4}{|l|}{ EFF1 } & \multicolumn{4}{|l|}{ EFF2 } \\
\hline & Coef. & $\mathrm{N}$ & F-test & $\mathrm{R}^{2}$ & Coef. & $\mathrm{N}$ & F-test & $\mathrm{R}^{2}$ & Coef. & $\mathrm{N}$ & F-test & R2 & Coef. & $\mathrm{N}$ & F-test & $\mathrm{R}^{2}$ \\
\hline Tier 1/rwa(-1)xIBDV & $\begin{array}{l}0.017 \\
(0.017)\end{array}$ & 2517 & $4.56^{* *}$ & 0.252 & $\begin{array}{l}0.038^{* * * *} \\
(0.016)\end{array}$ & 2312 & 1.18 & 0.271 & $\begin{array}{l}0.339 * * * \\
(0.076)\end{array}$ & 2100 & 2.4 & 0.619 & $\begin{array}{l}0.486 * * * \\
(0.093)\end{array}$ & 1854 & $9.17^{* * * *}$ & 0.543 \\
\hline Tier 1/rwa(-1)xCBDV & $\begin{array}{l}0.045 * * * \\
(0.045)\end{array}$ & & & & $\begin{array}{l}0.05 * * * \\
(0.010)\end{array}$ & & & & $\begin{array}{l}0.465 * * * \\
(0.079)\end{array}$ & & & & $\begin{array}{l}0.753^{* * * *} \\
(0.087)\end{array}$ & & & \\
\hline Tier 2/rwa(-1)xIBDV & $\begin{array}{l}0.025 \\
(0.057)\end{array}$ & 2778 & 0.00 & 0.193 & $\begin{array}{l}0.057 \\
(0.092)\end{array}$ & 2276 & 1.04 & 0.242 & $\begin{array}{l}-0.041 \\
(0.578)\end{array}$ & 2064 & 0.00 & 0.608 & $\begin{array}{l}-0.294 \\
(0.784)\end{array}$ & 1833 & 0.03 & 0.502 \\
\hline Tier 2/rwa(-1)xCBDV & $\begin{array}{l}0.028 \\
(0.029)\end{array}$ & & & & $\begin{array}{l}-0.034 \\
(0.035)\end{array}$ & & & & $\begin{array}{l}-0.004 \\
(0.260)\end{array}$ & & & & $\begin{array}{l}-0.155 \\
(0.283)\end{array}$ & & & \\
\hline $\begin{array}{l}\text { Total capital/rwa(-1) } \\
\text { xIBDV }\end{array}$ & $\begin{array}{l}0.023 \\
(0.015)\end{array}$ & 3835 & 2.69 & 0.199 & $\begin{array}{l}0.037 * * * \\
(0.014)\end{array}$ & 3288 & 1.38 & 0.247 & $\begin{array}{l}0.34 * * * \\
(0.063)\end{array}$ & 3066 & $3.3^{*}$ & 0.594 & $\begin{array}{l}0.469 * * * \\
(0.081)\end{array}$ & 2649 & $4.64 * *$ & 0.549 \\
\hline $\begin{array}{l}\text { Total capital/rwa(-1) } \\
\text { xCBDV }\end{array}$ & $\begin{array}{l}0.042 * * * \\
(0.007)\end{array}$ & & & & $\begin{array}{l}0.05 * * * \\
(0.008)\end{array}$ & & & & $\begin{array}{l}0.457 * * * \\
(0.067)\end{array}$ & & & & $\begin{array}{l}0.624 * * * \\
(0.067)\end{array}$ & & & \\
\hline Tier 1/ta(-1) xIBDV & $\begin{array}{l}0.029 \\
(0.034)\end{array}$ & 2804 & 1.99 & 0.205 & $\begin{array}{l}0.062 * * \\
(0.028)\end{array}$ & 2285 & 0.43 & 0.279 & $\begin{array}{l}0.493 * * * \\
(0.113)\end{array}$ & 2049 & $6.62^{* *}$ & 0.599 & $\begin{array}{l}0.6 * * * \\
(0.159)\end{array}$ & 1783 & $13.19^{* * *}$ & 0.525 \\
\hline Tier $1 / \mathrm{ta}(-1) \mathrm{xCBDV}$ & $\begin{array}{l}0.061 * * * \\
(0.018)\end{array}$ & & & & $\begin{array}{l}0.075^{* * *} \\
(0.017)\end{array}$ & & & & $\begin{array}{l}0.804 * * * \\
(0.141)\end{array}$ & & & & $\begin{array}{l}1.118^{* * * *} \\
(0.159)\end{array}$ & & & \\
\hline Tier 2/ta (-1)xIBDV & $\begin{array}{l}-0.01 \\
(0.149)\end{array}$ & 2747 & 0.44 & 0.179 & $\begin{array}{l}0.132 \\
(0.154)\end{array}$ & 2230 & 0.26 & 0.236 & $\begin{array}{l}0.768 \\
(0.869)\end{array}$ & 1996 & 0.46 & 0.578 & $\begin{array}{l}0.258 \\
(1.129)\end{array}$ & 1746 & 0.07 & 0.485 \\
\hline Tier $2 / \operatorname{ta}(-1) \times C B D V$ & $\begin{array}{l}0.084^{* * *} \\
(0.041)\end{array}$ & & & & $\begin{array}{l}0.06 \\
(0.044)\end{array}$ & & & & $\begin{array}{l}0.182 \\
(0.433)\end{array}$ & & & & $\begin{array}{l}-0.048 \\
(0.341)\end{array}$ & & & \\
\hline $\begin{array}{l}\text { Total capital/ta(-1) } \\
\text { xIBDV }\end{array}$ & $\begin{array}{l}0.03 \\
(0.033)\end{array}$ & 2981 & 2.44 & 0.206 & $\begin{array}{l}0.06 * * \\
(0.027)\end{array}$ & 2456 & 0.86 & 0.273 & $\begin{array}{l}0.53 * * * \\
(0.109)\end{array}$ & 2220 & $8.45^{* * *}$ & 0.607 & $0.593 * * *$ & 1933 & $12.0^{* * *}$ & 0.531 \\
\hline $\begin{array}{l}\text { Total capital/ta(-1) } \\
\text { xCBDV }\end{array}$ & $\begin{array}{l}0.063 * * * \\
(0.017)\end{array}$ & & & & $\begin{array}{l}0.077 * * * \\
(0.016)\end{array}$ & & & & $\begin{array}{l}0.848^{* * * *} \\
(0.134)\end{array}$ & & & & $\begin{array}{l}1.03 * * * \\
(0.135)\end{array}$ & & & \\
\hline $\begin{array}{l}\text { Common equity/ta(-1) } \\
\text { xIBDV }\end{array}$ & $\begin{array}{l}0.03^{*} \\
(0.016)\end{array}$ & 6211 & 1.67 & 0.167 & $\begin{array}{l}0.051 * * * \\
(0.013)\end{array}$ & 5423 & 0.49 & 0.218 & $0.527^{* * *}$ & 5165 & $2.73^{*}$ & 0.529 & $0.593 * * *$ & 4121 & $3.23^{*}$ & 0.511 \\
\hline Common equity/ta(-1) & $0.048 * * *$ & & & & $0.06 * * *$ & & & & $0.646^{* * * *}$ & & & & $0.736^{* * * *}$ & & & \\
\hline $\mathrm{xCBDV}$ & $(0.006)$ & & & & $(0.008)$ & & & & $(0.067)$ & & & & $(0.058)$ & & & \\
\hline Tangible equity/ta(-1) & $0.032 * *$ & 6211 & 1.97 & 0.171 & $0.053 * * *$ & 5423 & 0.67 & 0.221 & $0.531 * * *$ & 5165 & $3.42 *$ & 0.529 & $0.598^{* * * *}$ & 4121 & $3.14^{*}$ & 0.511 \\
\hline xIBDV & $(0.015)$ & & & & $(0.013)$ & & & & $(0.065)$ & & & & $(0.075)$ & & & \\
\hline $\begin{array}{l}\text { Tangible equity/ta(-1) } \\
\text { xCBDV }\end{array}$ & $\begin{array}{l}0.051^{* * * *} \\
(0.007)\end{array}$ & & & & $\begin{array}{l}0.063^{* * * *} \\
(0.008)\end{array}$ & & & & $\begin{array}{l}0.661 * * * * \\
(0.068)\end{array}$ & & & & $\begin{array}{l}0.736 * * * \\
(0.059)\end{array}$ & & & \\
\hline
\end{tabular}

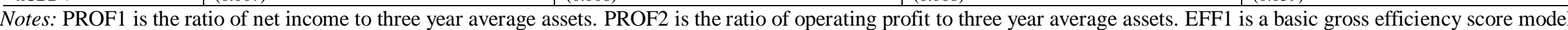

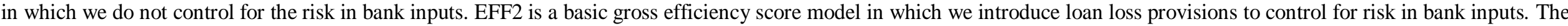

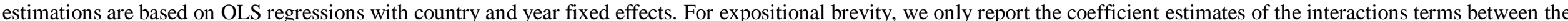

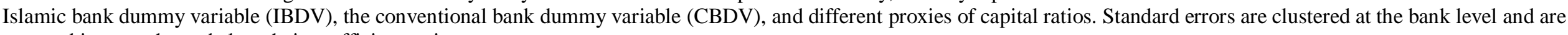
reported in parentheses below their coefficient estimates.

* denotes statistical significance at the $10 \%$ level.

** denotes statistical significance at the $5 \%$ level.

$* * *$ denotes statistical significance at the $1 \%$ level. 
Table 6

Other estimation techniques

Panel A: Truncated regressions approach

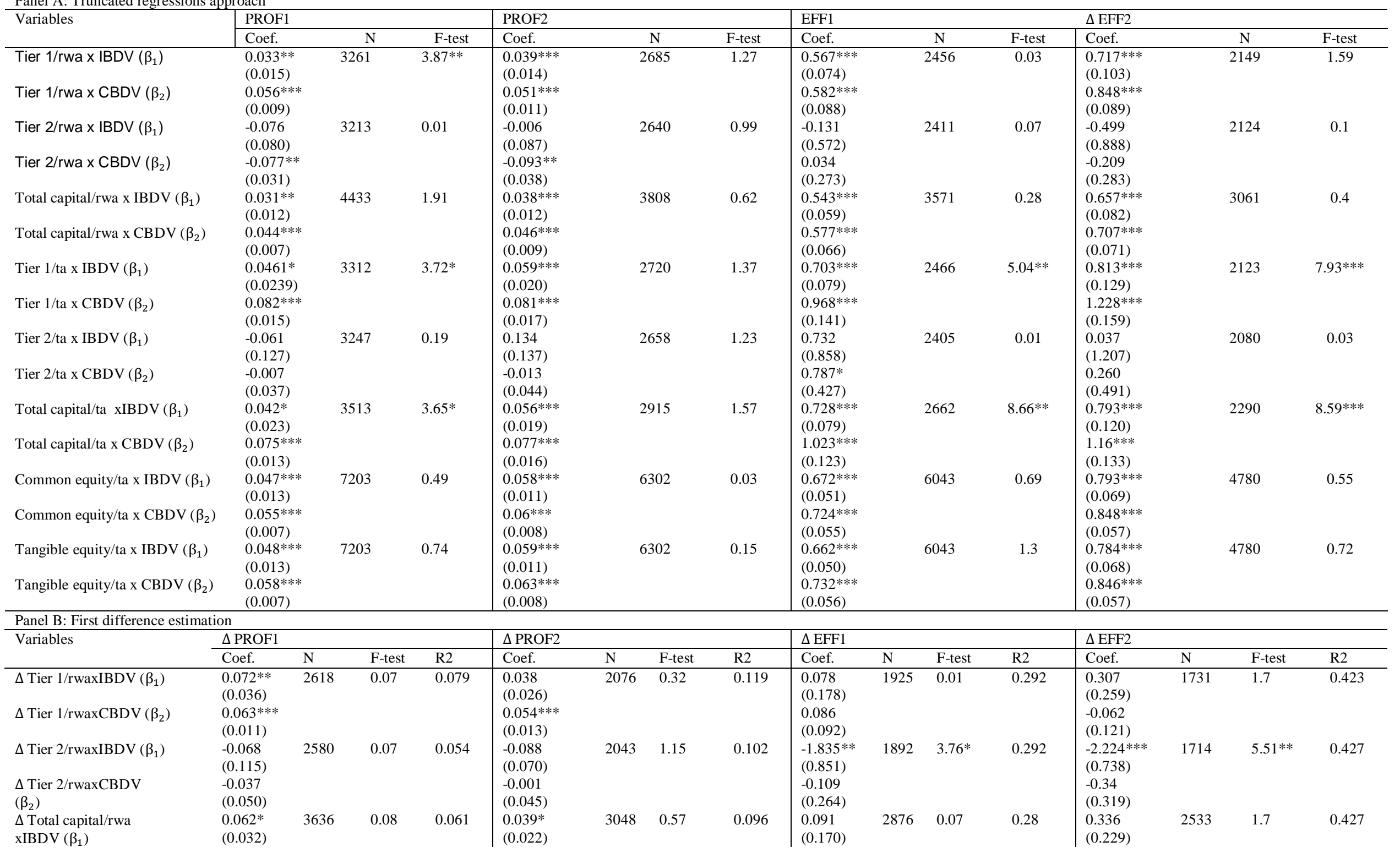




\begin{tabular}{|c|c|c|c|c|c|c|c|c|c|c|c|c|c|c|c|c|}
\hline $\begin{array}{l}\Delta \text { Total capital/rwa } \\
\text { xCBDV }\left(\beta_{2}\right)\end{array}$ & $\begin{array}{l}0.052 * * * \\
(0.009)\end{array}$ & & & & $\begin{array}{l}0.057 * * * \\
(0.011)\end{array}$ & & & & $\begin{array}{l}0.042 \\
(0.062)\end{array}$ & & & & $\begin{array}{l}0.027 \\
(0.078)\end{array}$ & & & \\
\hline$\Delta$ Tier $1 /$ ta xIBDV $\left(\beta_{1}\right)$ & $\begin{array}{l}0.201^{* *} \\
(0.080)\end{array}$ & 2666 & 0.19 & 0.091 & $\begin{array}{l}0.126^{* *} \\
(0.050)\end{array}$ & 2107 & 0.29 & 0.124 & $\begin{array}{l}0.400 \\
(0.307)\end{array}$ & 1927 & 0.01 & 0.277 & $\begin{array}{l}0.652 * * \\
(0.316)\end{array}$ & 1703 & 2.55 & 0.389 \\
\hline$\Delta$ Tier $1 /$ ta xCBDV $\left(\beta_{2}\right)$ & $\begin{array}{l}0.165 * * * \\
(0.037)\end{array}$ & & & & $\begin{array}{l}0.159 * * * \\
(0.040)\end{array}$ & & & & $\begin{array}{l}0.405 * * \\
(0.163)\end{array}$ & & & & $\begin{array}{l}0.048 \\
(0.223)\end{array}$ & & & \\
\hline$\Delta$ Tier $2 /$ ta xIBDV $\left(\beta_{1}\right)$ & $\begin{array}{l}-0.269 \\
(0.191)\end{array}$ & 2612 & 2.6 & 0.043 & $\begin{array}{l}-0.215^{* *} \\
(0.084)\end{array}$ & 2058 & $7.31^{* * *}$ & 0.08 & $\begin{array}{l}-1.716 \\
(1.221)\end{array}$ & 1878 & 1.71 & 0.273 & $\begin{array}{l}-3.727 * * * \\
(0.906)\end{array}$ & 1669 & $11.32^{* * * *}$ & 0.395 \\
\hline$\Delta$ Tier $2 /$ ta xCBDV $\left(\beta_{2}\right)$ & $\begin{array}{l}0.048 \\
(0.051)\end{array}$ & & & & $\begin{array}{l}0.052 \\
(0.055)\end{array}$ & & & & $\begin{array}{l}-0.03 \\
(0.402)\end{array}$ & & & & $\begin{array}{l}-0.395 \\
(0.444)\end{array}$ & & & \\
\hline $\begin{array}{l}\Delta \text { Total capital/ta xIBDV } \\
\left(\beta_{1}\right) \\
\Delta \text { Total capital/ta } \\
\text { xCBDV }\left(\beta_{2}\right)\end{array}$ & $\begin{array}{l}0.053 \\
(0.046) \\
0.129 * * * \\
(0.030)\end{array}$ & 2845 & 2.09 & 0.067 & $\begin{array}{l}0.027 \\
(0.032) \\
0.127 * * * \\
(0.033)\end{array}$ & 2282 & $5.08^{* *}$ & 0.10 & $\begin{array}{l}0.0765 \\
(0.136) \\
0.339 * * \\
(0.147)\end{array}$ & 2100 & 1.73 & 0.264 & $\begin{array}{l}0.084 \\
(0.125) \\
0.021 \\
(0.183)\end{array}$ & 1854 & 0.08 & 0.379 \\
\hline $\begin{array}{l}\Delta \text { Common equity/ta } \\
\text { xIBDV }\left(\beta_{1}\right) \\
\Delta \text { Common equity/ta } \\
\text { xCBDV }\left(\beta_{2}\right)\end{array}$ & $\begin{array}{l}0.099 * * * \\
(0.031) \\
0.109 * * * \\
(0.014)\end{array}$ & 6143 & 0.08 & 0.073 & $\begin{array}{l}0.074 * * * \\
(0.025) \\
0.104 * * * \\
(0.015)\end{array}$ & 5276 & 1.16 & 0.081 & $\begin{array}{l}0.835^{* * * *} \\
(0.157) \\
0.426 * * * \\
(0.090)\end{array}$ & 5059 & $5.65^{* *}$ & 0.268 & $\begin{array}{l}0.185 \\
(0.202) \\
0.097 \\
(0.106)\end{array}$ & 4016 & 0.15 & 0.382 \\
\hline $\begin{array}{l}\Delta \text { Tangible equity/ta } \\
\text { xIBDV }\left(\beta_{1}\right) \\
\Delta \text { Tangible equity/ta } \\
x \operatorname{CBDV}\left(\beta_{2}\right)\end{array}$ & $\begin{array}{l}0.105 * * * \\
(0.033) \\
0.127 * * * \\
(0.014)\end{array}$ & 6143 & 0.44 & 0.084 & $\begin{array}{l}0.077 * * * \\
(0.026) \\
0.128 * * * \\
(0.015)\end{array}$ & 5276 & $3.23 *$ & 0.094 & $\begin{array}{l}0.82 * * * \\
(0.127) \\
0.503 * * * \\
(0.097)\end{array}$ & 5059 & $4.42 * *$ & 0.27 & $\begin{array}{l}0.142 \\
(0.204) \\
0.174^{*} \\
(0.0999)\end{array}$ & 4106 & 0.02 & 0.382 \\
\hline
\end{tabular}

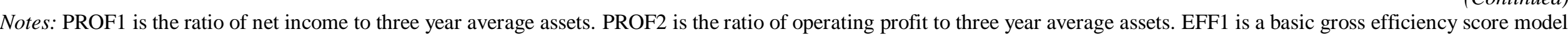

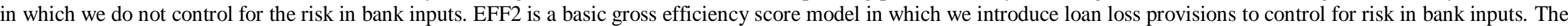

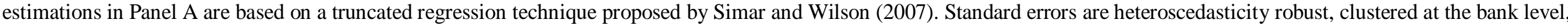

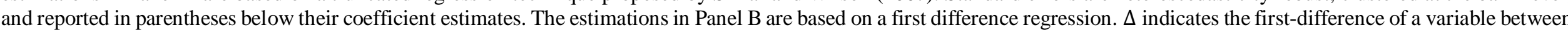

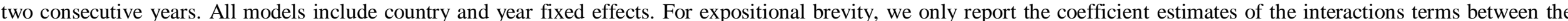

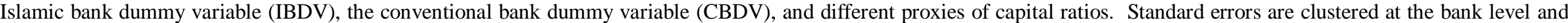
reported in parentheses below their coefficient estimates.

* denotes statistical significance at the $10 \%$ level.

$* *$ denotes statistical significance at the $5 \%$ level.

$* * *$ denotes statistical significance at the $1 \%$ level. 


\section{Figures}

Fig. 1. Quantile plots for the profitability measure (PROF1)
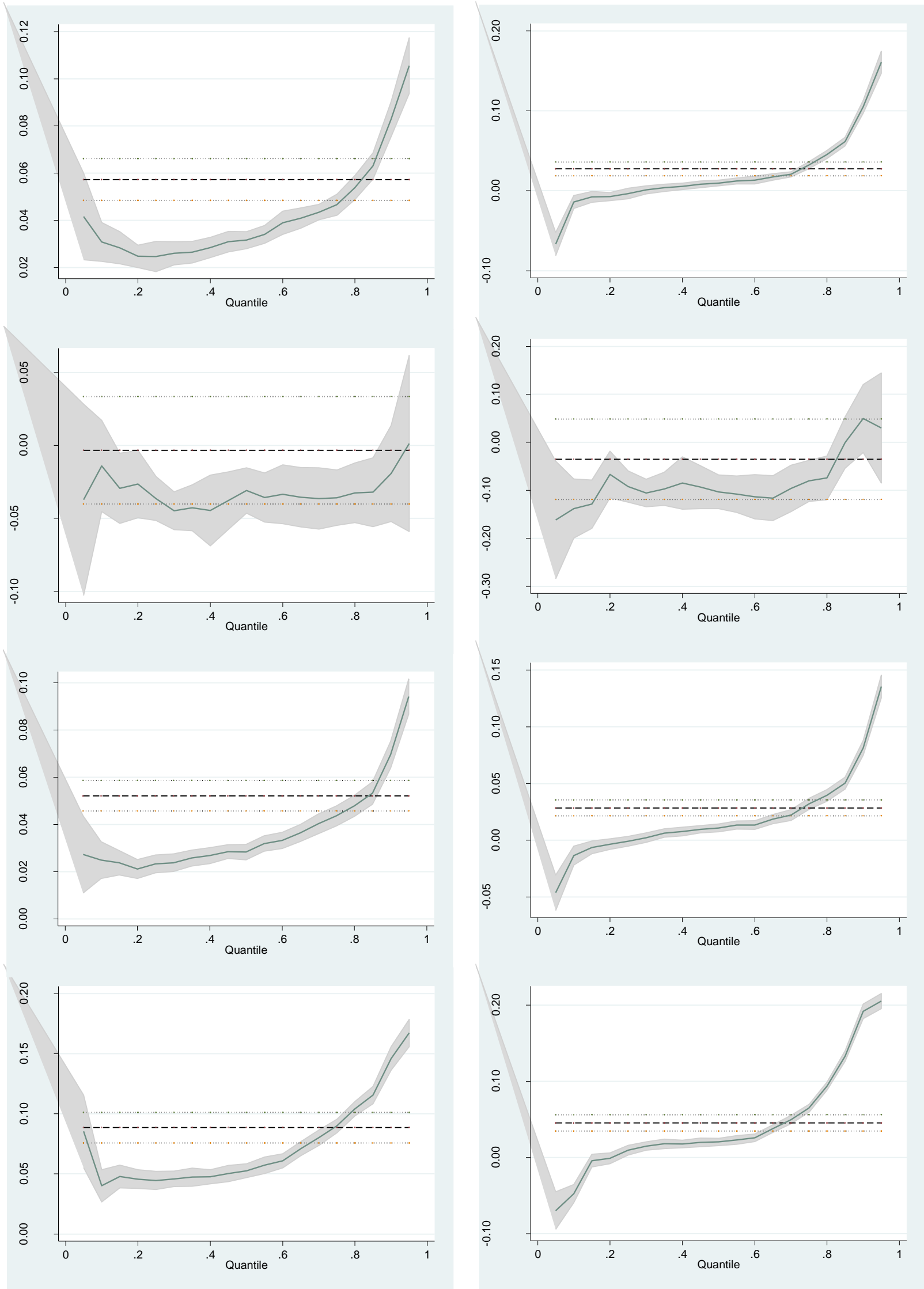

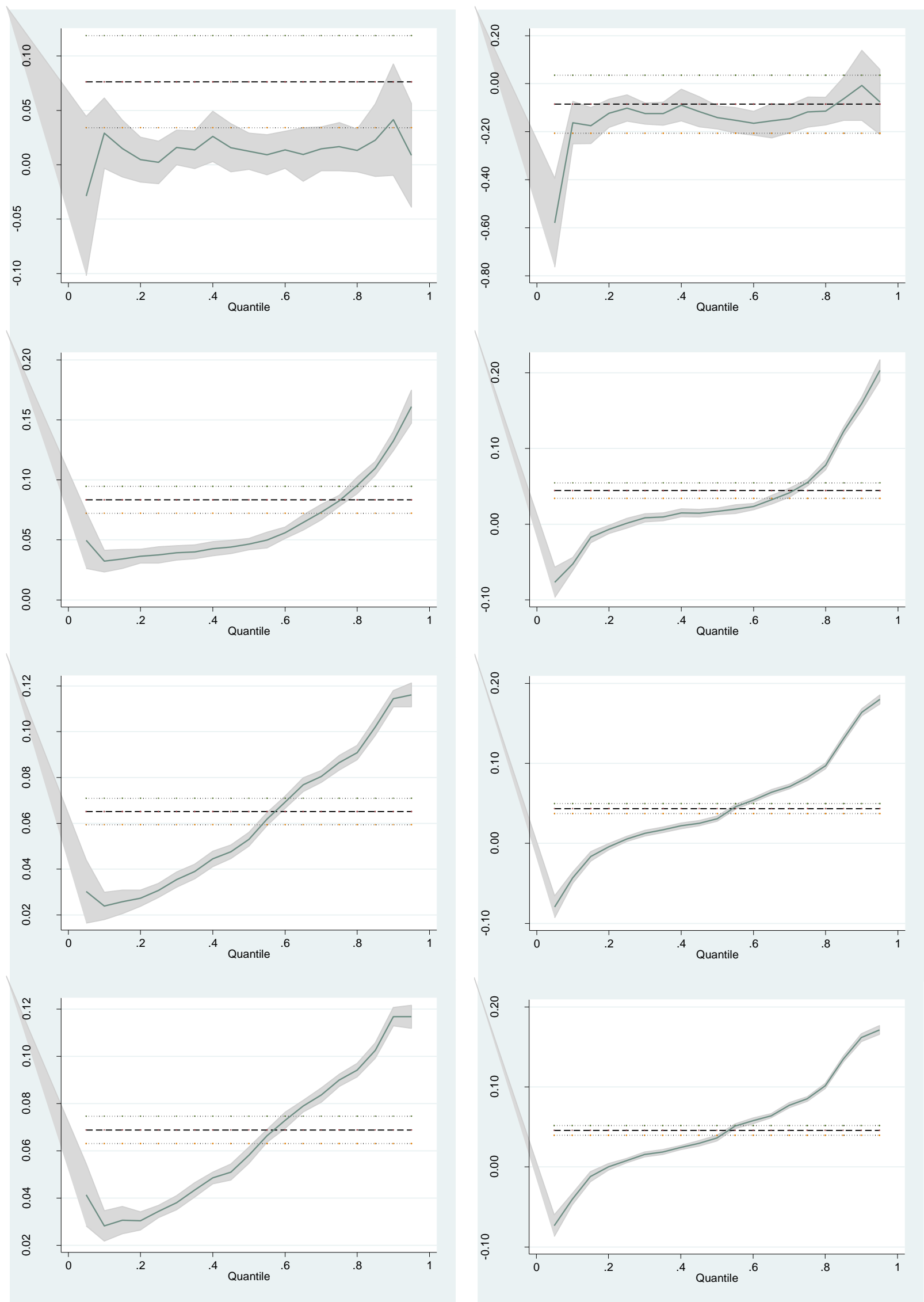
Fig. 2. Quantile plots for the efficiency measure (EFF1)
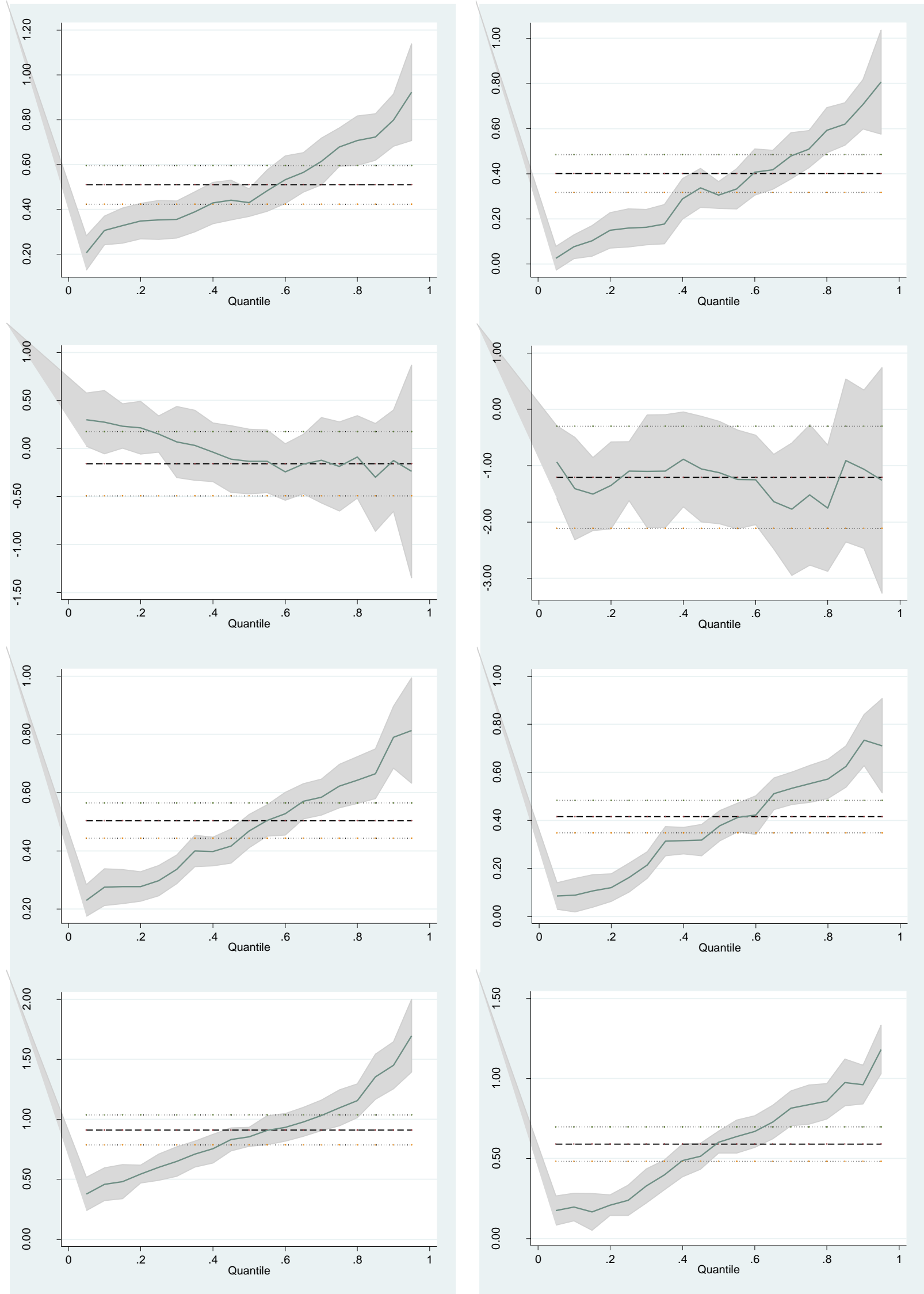

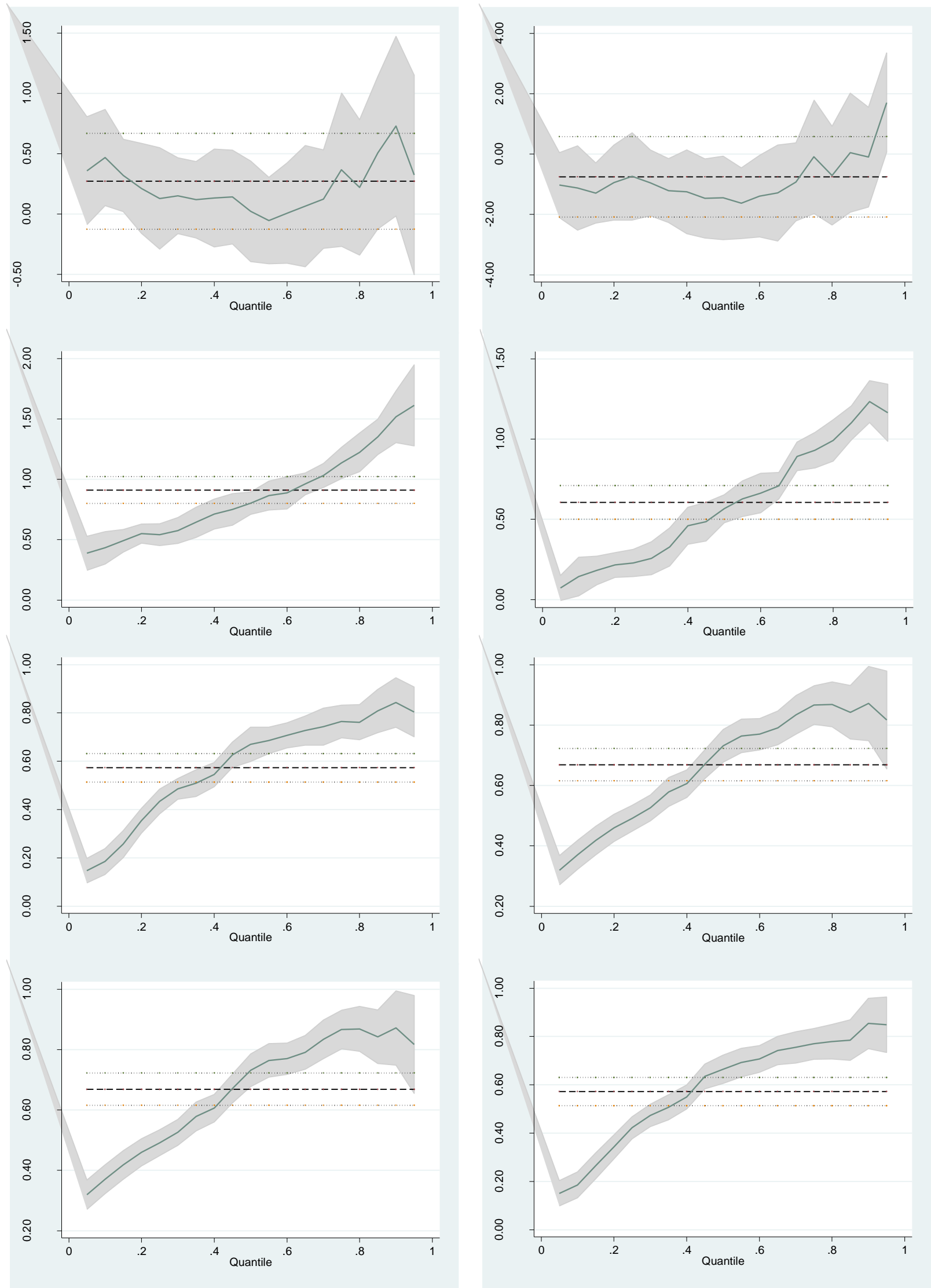